\title{
INVESTIGATION OF CONSTRUCTION MATERIAL QUALITY AND WORKMANSHIP DEFECTS OF RC BUILDINGS COLLAPSED AND SEVERELY DAMAGED IN THE 6.8 MW SIVRICE, ELAZIĞ, TURKEY, EARTHQUAKE, JANUARY 2020
}

\author{
Murat Bikçe $^{1}$ and Muhammet M. Erdem ${ }^{2}$
}

(Submitted July 2020; Reviewed August 2020; Accepted February 2021)

\begin{abstract}
In the Sivrice, Elazı $\breve{g}$, Turkey earthquake on January 24, 2020, 41 people lost their lives, more than 1600 people were injured, 672 buildings collapsed, and around 12600 buildings were severely damaged due to poor construction quality. After such devastating earthquakes, damage assessment and forensic investigations are normally carried out quickly for a judicial process, and material qualities are revealed. However, emotional sensitivity of the victims in the earthquake affected zone and disruptions in key lifeline services such as transportation, electricity supply often make these processes difficult. After the Elazıg earthquake, along with the conventional in-situ core sampling method, concrete pieces were collected from columns of collapsed and severely damaged buildings and transported out of the earthquake zone to overcome these adverse conditions. Unlike in the conventional method where the whole sampling process is carried out in the earthquake zone, the core extraction from the transported concrete pieces was carried out outside the earthquake-affected area. The extracted concrete samples were checked for compliance with the prevailing material standards. Moreover, multiple reinforcing bars of various diameters were also extracted and tested to check their compliance with the standards. Besides, the results of examination of the quality of materials and workmanship used in the construction are also discussed, along with the precautions required to minimize fatalities and damage from similar buildings.
\end{abstract}

\section{INTRODUCTION}

Turkey has been subjected to many destructive earthquakes because it is located in a seismically active area. Compared with other similar earthquakes globally, Turkey has generally suffered greater damage and fatalities from earthquakes [1]. When the data for the last century are examined, it is seen that more than 58 thousand fatalities, more than 122 thousand injuries, and more than 400 thousand damages or collapses have occurred due to the earthquakes [2]. One of the latest destructive earthquake series in Turkey is the $6.8 \mathrm{Mw}$ Sivrice (Elazığ) earthquake, which occurred on January 24, 2020, in Sivrice district of Elazığ, at a depth of 8.6 kilometres. The epicentre of the earthquake $\left(38.3593^{\circ} \mathrm{N}, 39.0630^{\circ} \mathrm{E}\right)$ (Figure 1) was approximately $36.47 \mathrm{~km}$ away from the city centre of Elazığ [3-7]. The maximum acceleration values measured at a station, which is 24 kilometres away from the epicentre, are as follows: North-South direction $0.240 \mathrm{~g}(2.358 \mathrm{~m} / \mathrm{s} 2$, East-West direction $-0.298 \mathrm{~g}(-2.928 \mathrm{~m} / \mathrm{s} 2)$ and in the vertical direction $0.182 \mathrm{~g}(1.786 \mathrm{~m} / \mathrm{s} 2)$ as seen in Figure 2 [8].

Within one month after the earthquake, a total of 3087 aftershocks occurred, 26 of which were greater than 4.0 magnitude [3]. During the earthquake, 263 buildings collapsed in Elazı ğ [9], 4 of which are multi-story reinforced concrete structures. The rest of the collapsed buildings are 1-2 story masonry, adobe, or non-engineered reinforced concrete structures, located in settlements near the epicentre, in a mountainous and rural area. Three of the collapsed multi-story reinforced concrete structures are located in the city centre of Elazığ, about $36 \mathrm{~km}$ from the epicentre, and one in the resort of Gezin, about $43 \mathrm{~km}$ away. As a consequence of the earthquake,
37 people in Elazığ, and 4 people in Malatya lost their lives under the collapsed buildings. Out of these, 33 fatalities occurred in multi-story RC buildings in Elazığ, and 8 deaths occurred in non-engineered houses located in the rural areas in Elazığ and Malatya provinces. Besides, 45 people were saved from the wreckage, and 1631 people were injured (admitted to hospitals for earthquake-related reasons) [10].

Despite all the research and awareness on the subject, earthquakes worldwide still lead to fatalities, in addition to structural and financial losses. Many researchers from different regions of the world have published their observations and reported lessons to be learnt to reduce future earthquake losses. These include investigations from different perspectives such as masonry structure damages [12,13], retrofitted building damages [14], industrial structure damages [15], non-structural element damages [16-20], residential house damages [21,22], school building damages [23] and lifeline system damages [24], and extensive damage assessments $[25,26]$. When damaged or collapsed buildings were examined in past earthquakes, poor quality of concrete and reinforcement were most commonly noticed in Turkey $[5,27-30]$. According to the past Turkish Earthquake Codes (TEC), the minimum concrete class to be used in buildings was defined as $25 \mathrm{MPa}$ in 2018 TEC [31] and $20 \mathrm{MPa}$ in the 1998 and 2007 TECs [32, 33]. In the 1975 version of TEC [34], the minimum concrete strength was defined as $225 \mathrm{~kg} / \mathrm{cm}^{2}$ for $20 \times 20 \times 20 \mathrm{~cm}^{3}$ cubic samples in buildings with a significance factor greater than 1 . The cube strength limit was revised in the later versions of the code by converting it to cylindrical strength. 


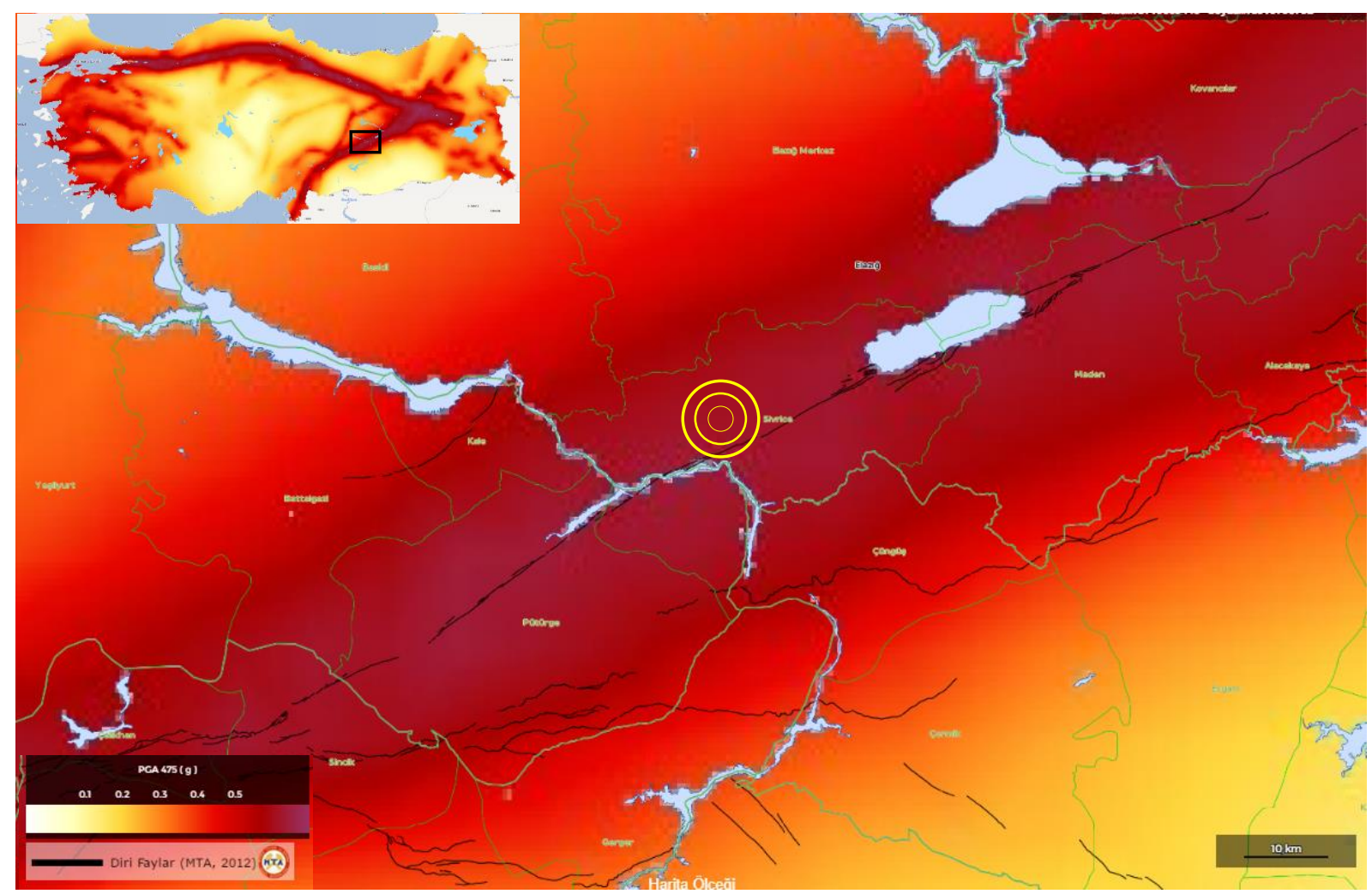

Figure 1: General PGA map of Elazı̆ area [11].
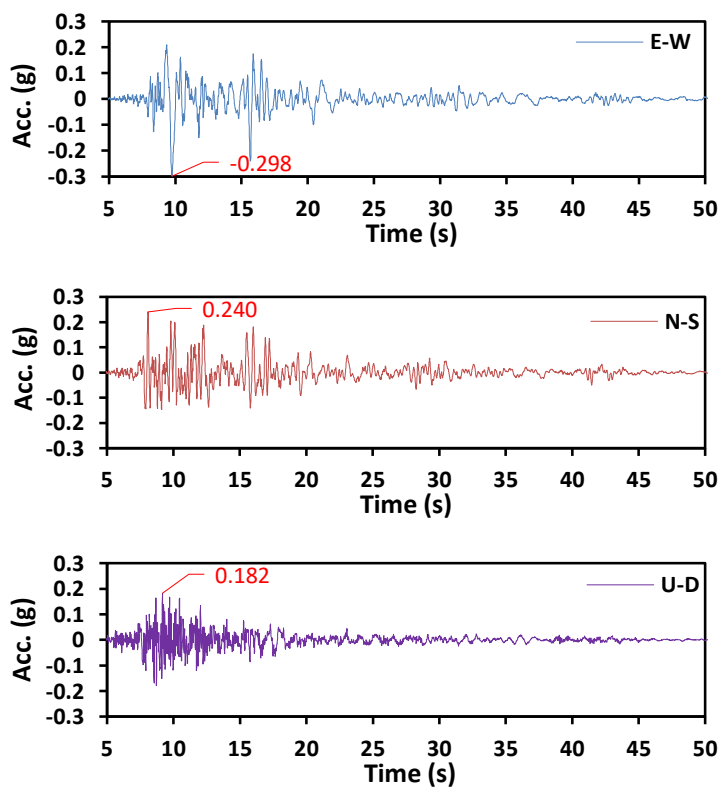

Figure 2: Acceleration records in Sivrice Station [8].

Thanks to the more refined regulations on quality and compliance requirements of the updated TECs, the number of fatalities and damage have decreased in the recent earthquakes. However, it has not been prevented completely [35-37]. Overall observations also indicated that the concrete quality was poorer in the severely damaged/collapsed buildings in the last earthquakes. Bekdas et al. [38] assessed the quality of the damaged buildings' construction materials after the earthquake in Van, Turkey. They investigated potential reasons (such as aggregate grading, concrete placement and compaction, workmanship etc) for damage to RC buildings by compression tests, X-ray diffraction, and scanning electron microscopy analyses on the concrete samples extracted from the collapsed/damaged buildings. It has been found that design errors, low material strength, inspection deficiencies, and poor workmanship are some of the reasons why the damage has been greater in these earthquakes [39]. The fact is that reducing the material strength is not a way of cost reduction in the long term [40]. Lack of cement quantity, inappropriate aggregate gradation, unwashed sea sand, inadequate cement paste, high water-cement ratio, casting concrete during unfavourable weather conditions, re-tempering concrete to increase the workability, short curing/vibration period, and lack of inspection are the reasons for the low quality of concrete. As for reinforcement, defective manufacturing, loss of mechanical properties as a result of physical and chemical reaction, corrosion, and reduced cross-sectional area of reinforcement cause a decrease in strength $[41,42]$.

Regarding the Elazığ earthquake and aftershocks, the number of studies on concrete and reinforcement strength is rather limited [5]. However, the information on the region's current seismicity, ground motion acceleration, acceleration response spectra, and types of damage in buildings can be found in several sources [3-7,43]. For instance, in the report prepared by the Turkish Ready Mixed Concrete Association [5], general observations about the earthquake area have been conveyed. It has been stated that the concrete strengths obtained from the buildings are in the range of 6-12 MPa. Most of the past earthquake investigations available in literature have reported the general damage observations [44-48]. On the other hand, the quality of construction material is thought to be a fundamental cause of damage that must be examined.

In this study, 35 concrete and 12 reinforcement samples were collected from 4 buildings that collapsed during the earthquake despite the practical and physical difficulties. Besides, 69 concrete and 70 reinforcement samples were also collected from severely damaged buildings demolished immediately after the earthquake (Figure 3). However, immediately after destructive earthquakes, the focus is rightly on rescuing people from the wreckage of collapsed buildings and the damage assessment can only be conducted after the wreckage has been removed. On the other hand, disruption to the electricity and water-supply networks, affecting vital needs of people, and the 

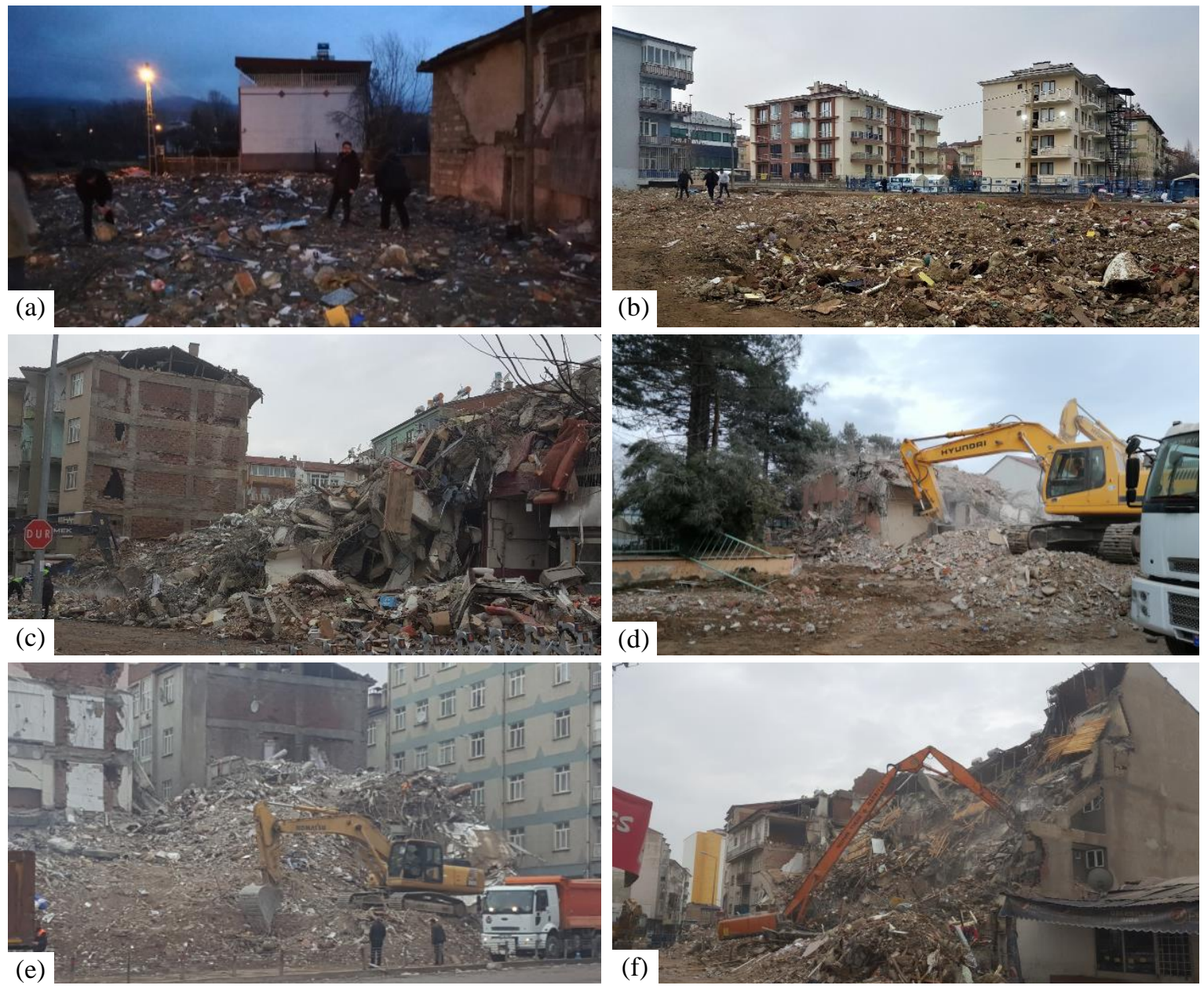

Figure 3: Some of the collapsed and severely damaged buildings from which the material samples were taken in Elazığ; (a) C01, (b) C02, (c) C04, (d) D05, (e) D12, (f) D18.

atmosphere make damage assessment difficult. Determining the damaged/collapsed buildings' material characteristics and removing the wreckage is essential in returning to everyday life in the earthquake zone. However, the capacity of the laboratories in the earthquake area cannot meet the required test demands. In additional to the conventional onsite extraction, transporting the samples to neighbouring cities was considered a practical solution. It was expected to accelerate the process of determining the material properties. The samples were taken from the collapsed/severely damaged buildings by extracting core samples after transporting big concrete pieces to a laboratory to examine the material properties.

During the examinations, many structures with corroded reinforcement were found. Rounded river/lake aggregates and concrete containing organic materials were also encountered. On the other hand, critical deficiencies were observed in the detailing of reinforcement. In particular, defects related to the stirrup spacing and length of lap splices were frequently encountered. Besides, examples such as installing various electric/water lines and accessories by damaging the structural elements, improper concrete placement, and short gaps between adjacent buildings were also encountered. In this paper, the detected design and workmanship defects that may have caused damage are presented with examples and recommendations are made to minimize damages.

\section{EXAMINATION OF THE MATERIAL PROPERTIES OF THE SEVERELY DAMAGED AND COLLAPSED BUILDINGS}

The use of ready-mixed concrete in Turkey started in 1976. However, it began to be used in the constructions in Elazığ after the year 1991. However, in a study conducted by Oymael and Yeginobalı [49], it is stated that in one of the 2 concrete plants operating in the early 1990s, C16 and C20 quality concrete mixes were made. In contrast, the other plant mixed the concrete based on experience without any mix design. Readymixed concrete facilities met $0.52 \%$ of the concrete demand in Elazığ during the first years of operation, while the remaining demand was met with manual mixing onsite [49]. As a result, the old RC buildings' concrete quality in the area is low.

In this study, concrete and reinforcement pieces were collected from the collapsed and severely damaged buildings soon after the earthquake (Figure 3). The coding of all collected samples is explained in Figure 4, including the building's condition, building code, the material of the sample, sample number, and sampling method. The transportable-sized concrete pieces were taken from the vertical structural members as much as possible, allowing extraction of solid and unreinforced core samples without visible cracks. Thus, more concrete samples could be obtained in a shorter time, and the core extracting was performed comfortably and safely in a laboratory outside the earthquake zone (Figure 5a,b). Besides, tensile tests of the collected steel bar samples were also performed (Figure 6).

\section{Material Properties in Collapsed Buildings}

Concrete core samples and reinforcement coupons of different diameters were collected from 4 collapsed buildings. As a result of site examinations, most collapsed buildings have been found to be constructed with hand-poured concrete mixed on-site by the workers without engineering service. Figures $3 \mathrm{a}-\mathrm{f}$ show some of the buildings from which the material samples were collected. 


\section{$\underline{\mathrm{Sd}} \underline{01}-\underline{\mathrm{C}} 01 \underline{\mathrm{T}} \quad$ (For concrete samples)}

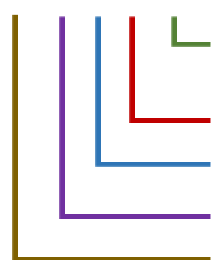

(a)

Sample number

Building number

Co" for Collapsed;

Sampling type: "T" for Transported;

"O" for conventional $\mathbf{O n}$-site extracted

Material of sample: "C" for Concrete

"Sd" for Severely damaged building

\section{$\underline{\mathrm{Sd}} \underline{\text { 02- }} \underline{\mathrm{R} 01}$ (For reinforcement samples)}

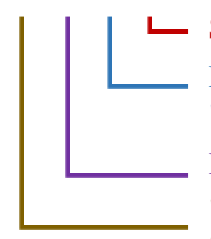

Sample number

Material of sample:

"R” for Reinforcement

Building number

"Co" for Collapsed;

"Sd" for Severely damaged building

(b)

Figure 4: Coding of (a) concrete and (b) reinforcement samples.
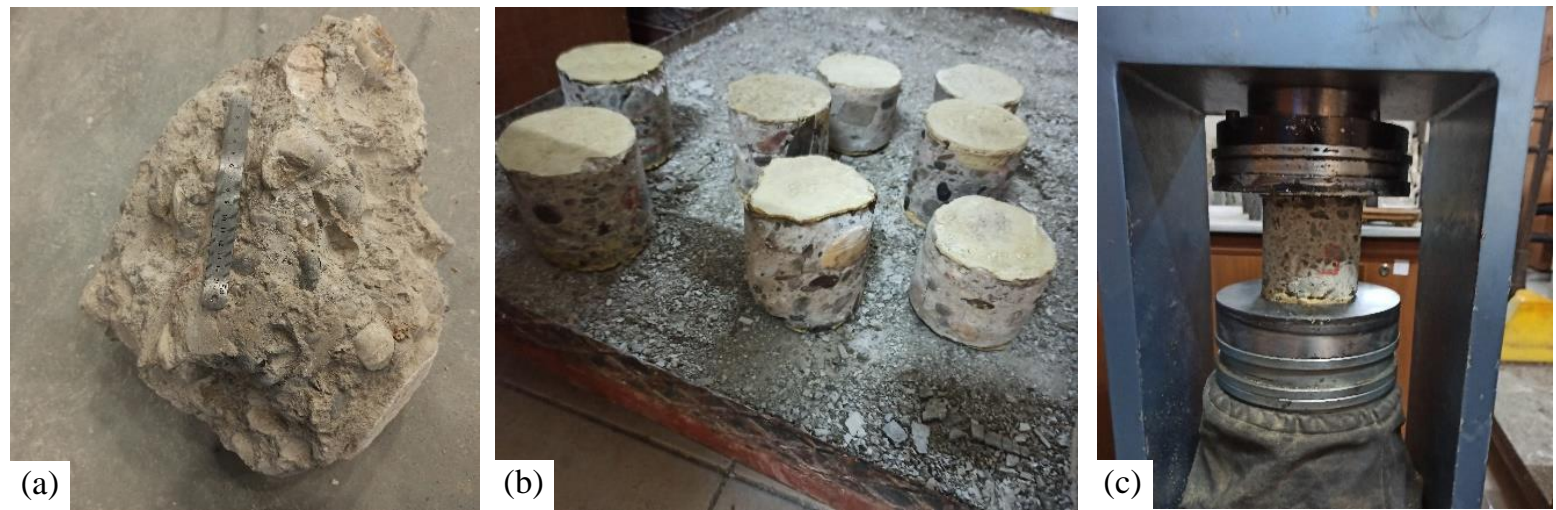

Figure 5: (a) A large piece of concrete and (b) core samples, (c) concrete compression test.
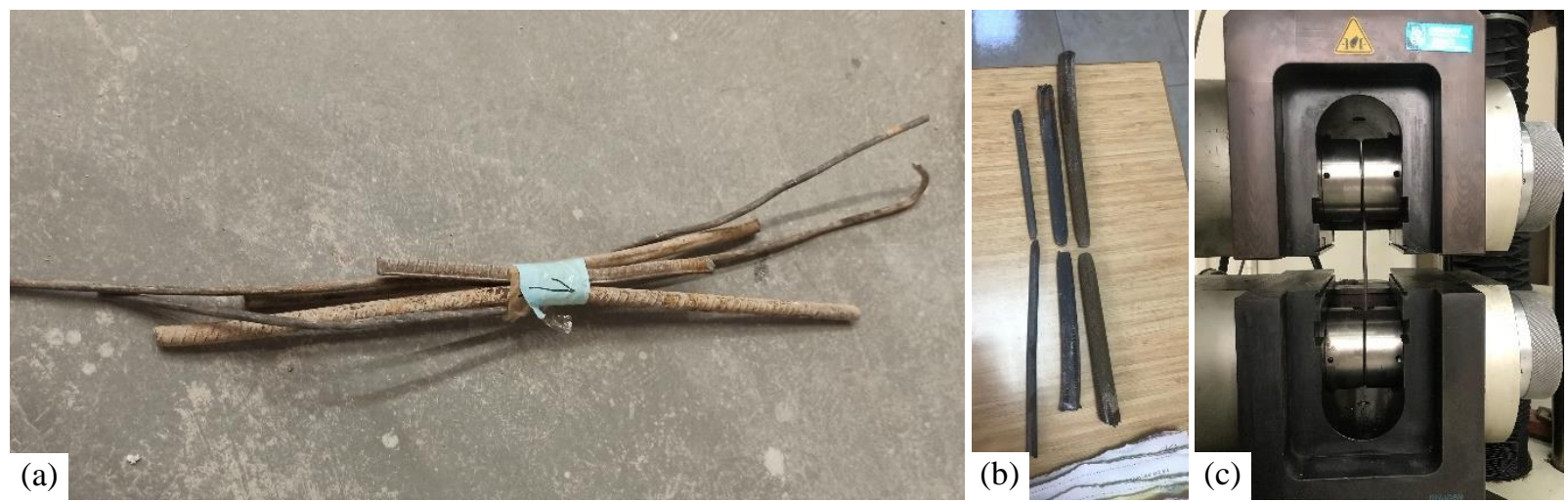

Figure 6: (a) Reinforcement taken from a collapsed buildings' column, (b) tested reinforcement, (c) tension test of a rebar.

Naturally, it was probable that the concrete cores might have some invisible micro-cracks, which may have affected their compressive strength. However, the authors still preferred the transport method due to the earthquake site's difficulties, as stated before. In addition to the decrease in the strength on account of the micro cracks, there is also an increase in the material strength depending on the time. Thus, in this study, the compressive strengths are presented as obtained from the tests, without adjusting for the factors that may affect the strength.

After the earthquake, 11 cores were extracted from the transported concrete pieces and 12 reinforcement samples were collected from 4 collapsed buildings. To attain a solid core's compressive strength, it was intended to get the cores from the non-segregated, unharmed, and void-free parts. The core samples were tested under the relevant standards [50,51]. Other 24 core samples were taken from the collapsed buildings via the conventional on-site method and tested.

In uniaxial unconfined compression tests, the friction between the loading plates and the samples causes lateral stresses. However, if the height to diameter ratio is 2 , lateral stresses in the samples' middle regions disappear and correct results are obtained. However, it is common to encounter situations where the height to diameter ratio requirement cannot be met in core samples. The core samples tested in this study also have the height to diameter ratio equal to 1 . For this reason, all the compressive strength values were multiplied with the correction factor "0.87" as recommended in the ASTM C42 standard [52]. The corrected compressive strengths of the core samples have been presented in Figure 7.

As shown in Figure 7, the highest concrete compressive strength value for the collapsed buildings was $14.43 \mathrm{MPa}$, while the lowest was $4.48 \mathrm{MPa}$. Overall the mean concrete strength was calculated as $9.58 \mathrm{MPa}$ (extremely low). Since the oldest one among the four collapsed buildings was constructed in 1987, TEC 1975 and the following TECs are used here for comparison and discussion. According to the Turkey Earthquake Zones Map [53], the Sivrice district near the epicentre is located in a $1^{\text {st }}$-degree seismic zone. However, the city centre of Elazı $\breve{g}$ is situated in a $2^{\text {nd }}$-degree seismic zone [53]. Therefore, the minimum concrete strength requirement for 1975 TEC in Figure 7 is shown for these seismic zones.

The concrete classes of the buildings required as per their design project are not known. To evaluate the quality of concrete, the core samples' compressive strength was compared with the minimum strength requirements stated in TECs (Figure 7). There is no damaged/collapsed building built according to 


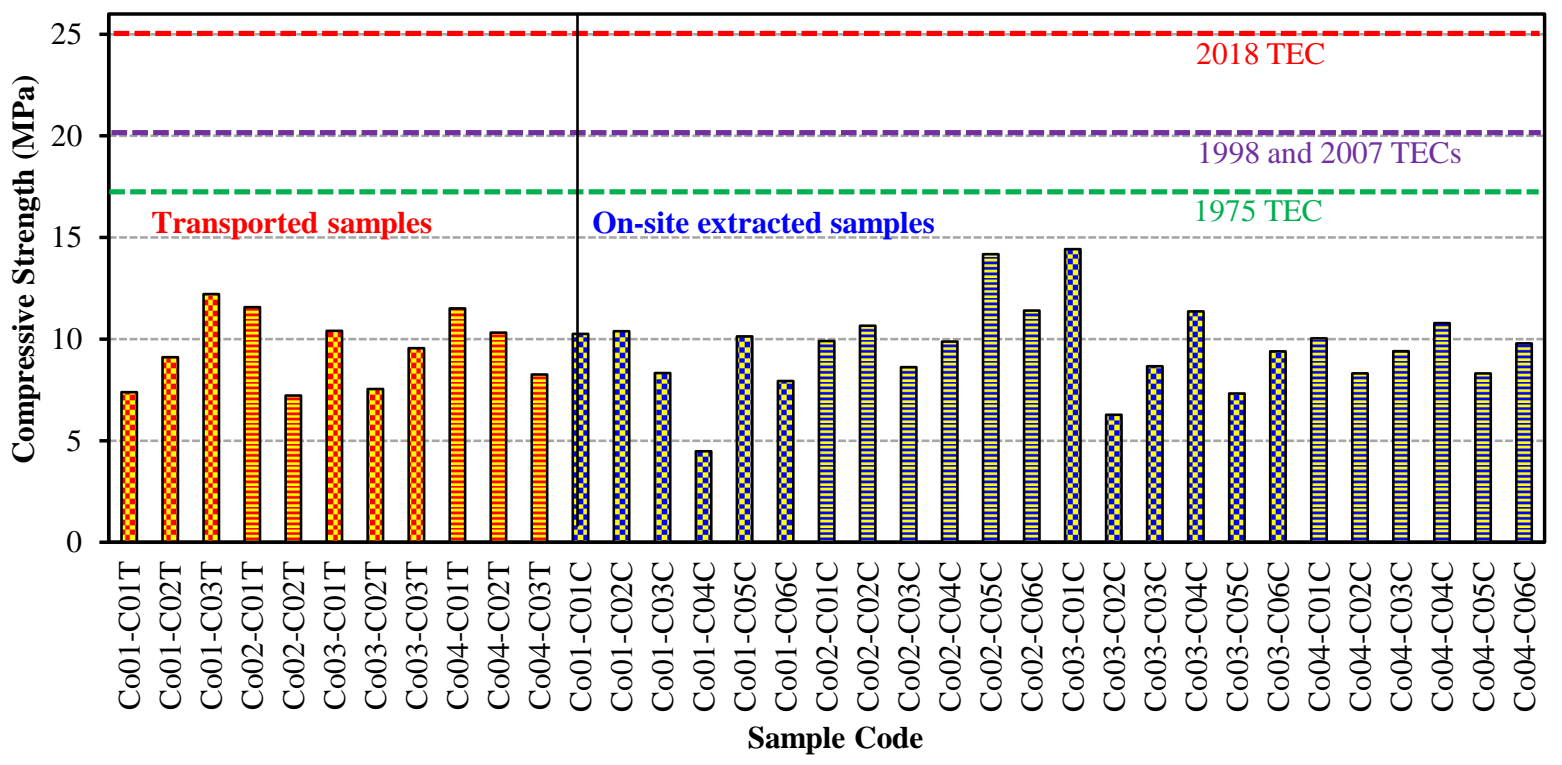

Figure 7: Compressive strengths of the concrete core samples of collapsed buildings.

2018 TEC [31]. The minimum compressive strength requirement is also marked in all charts (Figures 7-9,15). According to Figure 7, it is obvious that the collapsed buildings had lower concrete strength values compared to the minimum value stated in the relevant earthquake codes.

While S220 class [54] plain reinforcing bars were used in most buildings in Elazı ğ before the 2000s, S420 class [54] ribbed bars have become more common since the beginning of 2000 .

Having a sufficient number of reinforcement pieces in adequate lengths, samples meeting the nominal diameter standard were selected. Reinforcement samples in various diameters taken from the collapsed buildings were tested to determine if they were in line with the relevant standard [54] and regulations [3234] (Figure 6). As a result of the tests, the ratio of elongation at rupture, ultimate tensile strength, yield strength, and ultimate tensile strength/yield strength ratio values, along with the examination of these values, are listed in Table 1.

The reinforcement samples from the collapsed buildings that did not comply with the standard [54] are marked in Table 1 as
"X." Among all the reinforcement samples taken from the collapsed buildings, at least one sample that did not comply with the standard was found in each building (Table 1). As seen in Table 1, some reinforcement samples' yield strengths are much higher than the nominal yield strengths. According to the steel classification standard in force when constructing these buildings, the yield strength had to be higher than the nominal yield strength. It was enough for the manufacturers to achieve this strength by adding carbon to molten scrap steel, regardless of any upper yield strength limit. For this reason, it was possible to encounter samples with a yield strength exceeding the nominal yield strength in the buildings examined.

\section{Material Properties in Severely Damaged Buildings}

After the demolition of severely damaged buildings, core samples were collected by both transporting and conventional on-site extracting methods. 69 core samples from 18 severely damaged buildings were collected and tested. The average diameter of the core samples was $105 \mathrm{~mm}$. The height with capping was $105 \mathrm{~mm}$, and the height to diameter ratio was 1 .

Table 1: Tensile test results of reinforcement samples of collapsed buildings.

\begin{tabular}{|c|c|c|c|c|c|c|c|c|c|c|c|c|}
\hline $\begin{array}{l}\text { Sample } \\
\text { Code }\end{array}$ & $\begin{array}{l}\text { Reinf. } \\
\text { Type }\end{array}$ & $\begin{array}{c}\text { Nominal } \\
\text { Diameter } \\
\text { mm }\end{array}$ & $\begin{array}{c}\text { Measured } \\
\text { Diameter } \\
\text { mm }\end{array}$ & $\begin{array}{c}\text { Rupture } \\
\text { Elongation } \\
\% \\
\end{array}$ & I & $\begin{array}{c}\text { Yield } \mathbf{S t}^{\text {II }} \\
\mathbf{N} / \mathbf{m m}^{2} \\
\end{array}$ & III & IV & $\begin{array}{c}\text { Tensile } \\
\text { St. } \\
\text { N/mm } \\
\end{array}$ & VI & $\begin{array}{c}\text { V/II } \\
\% \\
\end{array}$ & VII \\
\hline Co01-R01 & S220 & 8.0 & 7.8 & 13.18 & $\mathrm{X}$ & 421.5 & $\sqrt{ }$ & - & 431.3 & $\sqrt{ }$ & 1.02 & $\mathrm{X}$ \\
\hline Co01-R02 & S220 & 8.0 & 7.9 & 28.15 & $\sqrt{ }$ & 430.3 & $\sqrt{ }$ & - & 614.3 & $\sqrt{ }$ & 1.43 & $\sqrt{ }$ \\
\hline Co01-R03 & $\mathrm{S} 220$ & 14.0 & 13.6 & 17.39 & $X$ & 490.1 & $\sqrt{ }$ & - & 501.2 & $\sqrt{ }$ & 1.02 & $X$ \\
\hline Co02-R01 & S220 & 8.0 & 8.0 & 30.05 & $\sqrt{ }$ & 379.3 & $\sqrt{ }$ & - & 523.3 & $\sqrt{ }$ & 1.38 & $\sqrt{ }$ \\
\hline Co02-R02 & $\mathrm{S} 220$ & 16.0 & 16.1 & 16.69 & $X$ & 278.4 & $\sqrt{ }$ & - & 402.3 & $\sqrt{ }$ & 1.45 & $\sqrt{ }$ \\
\hline Co02-R03 & $\mathbf{S 4 2 0}$ & 16.0 & 16.1 & 22.50 & $\sqrt{ }$ & 400.1 & $\mathrm{X}$ & $\sqrt{ }$ & 654.9 & $\sqrt{ }$ & 1.64 & $\sqrt{ }$ \\
\hline Co03-R01 & $\mathrm{S} 220$ & 8.0 & 8.1 & 42.62 & $\sqrt{ }$ & 456.6 & $\sqrt{ }$ & - & 666.2 & $\sqrt{ }$ & 1.46 & $\sqrt{ }$ \\
\hline Co03-R02 & $\mathrm{S} 220$ & 14.0 & 13.7 & 25.24 & $\sqrt{ }$ & 359.6 & $\sqrt{ }$ & - & 412.5 & $\sqrt{ }$ & 1.15 & $\mathrm{X}$ \\
\hline Co03-R03 & $\mathrm{S} 220$ & 16.0 & 15.8 & 25.74 & $\sqrt{ }$ & 264.1 & $\sqrt{ }$ & - & 415.1 & $\sqrt{ }$ & 1.57 & $\sqrt{ }$ \\
\hline Co04-R01 & $\mathrm{S} 220$ & 8.0 & 8.0 & 35.67 & $\sqrt{ }$ & 433.9 & $\sqrt{ }$ & - & 452.3 & $\sqrt{ }$ & 1.04 & $\mathrm{X}$ \\
\hline Co04-R02 & $\mathrm{S} 220$ & 16.0 & 16.0 & 9.42 & $\mathrm{X}$ & 536.9 & $\sqrt{ }$ & - & 557.9 & $\sqrt{ }$ & 1.04 & $X$ \\
\hline Co04-R03 & $\mathrm{S} 220$ & 16.0 & 15.7 & 32.76 & $\sqrt{ }$ & 459.3 & $\sqrt{ }$ & - & 513.5 & $\sqrt{ }$ & 1.12 & $\mathrm{X}$ \\
\hline
\end{tabular}

I: Rupture elongation control is $18 \%$ for $\$ 200$ and $10 \%$ for $S 420$.

II: Yield strength

III: Minimum yield strength control is $220 \mathrm{MPa}$ for $S 220$ and $420 \mathrm{MPa}$ for S420.

IV: Actual/characteristic yield strength control is 1.30 (for S420 only)

$V:$ Ultimate tensile strength

VI: Minimum tensile strength control is $340 \mathrm{MPa}$ for $S 220$ and $500 \mathrm{MPa}$ for S420.

VII: Ultimate tensile strength/yield strength control is 1.20 for S220 and 1.15 for S420. 
The correction factor recommended in ASTM C42 [52] was also applied to these samples. The compressive strength values in comparison to the relevant standards [50,51] are provided in Figure 8. Since the sample codes in horizontal axis labels do not fit on the axis in Figure 8, only the first sample code of each building is written. Unlabelled codes that follow the labelled samples belong to the other samples belonging to the same building. The severely damaged oldest building examined in this study was built in 1989 . For this reason, the concrete class requirement according to 1975 TEC is also marked in Figure 8. The concrete compressive strength values of the core samples that belong to the severely damaged buildings are as follows: 23.25 MPa the highest, 3.60 MPa the lowest and 8.37 MPa the mean.

The mean compressive strength values of each building are summarized in Figure 9, including the samples of collapsed/severely damaged buildings collected via both transport and conventional onsite methods. It is clear from Figure 9 that the buildings' compressive strength values, except one, do not match the minimum strength requirements. When their compressive strength is considered, it is understood that these buildings were designed without engineering service or built without inspection.

70 reinforcement samples with various diameters from 18 different severely damaged buildings were examined to check their compliance with the relevant standards [54] and earthquake codes [32-34]. The reinforcement samples were taken from the wreckage after demolition. The results of those samples are given in Table 2. As in the reinforcements (Table 1) of collapsed buildings, samples with a yield strength much higher than the nominal yield strength also stand out in severely damaged buildings (Table 2). It is seen that a considerable amount of the reinforcement samples did not fulfil the relevant standards.

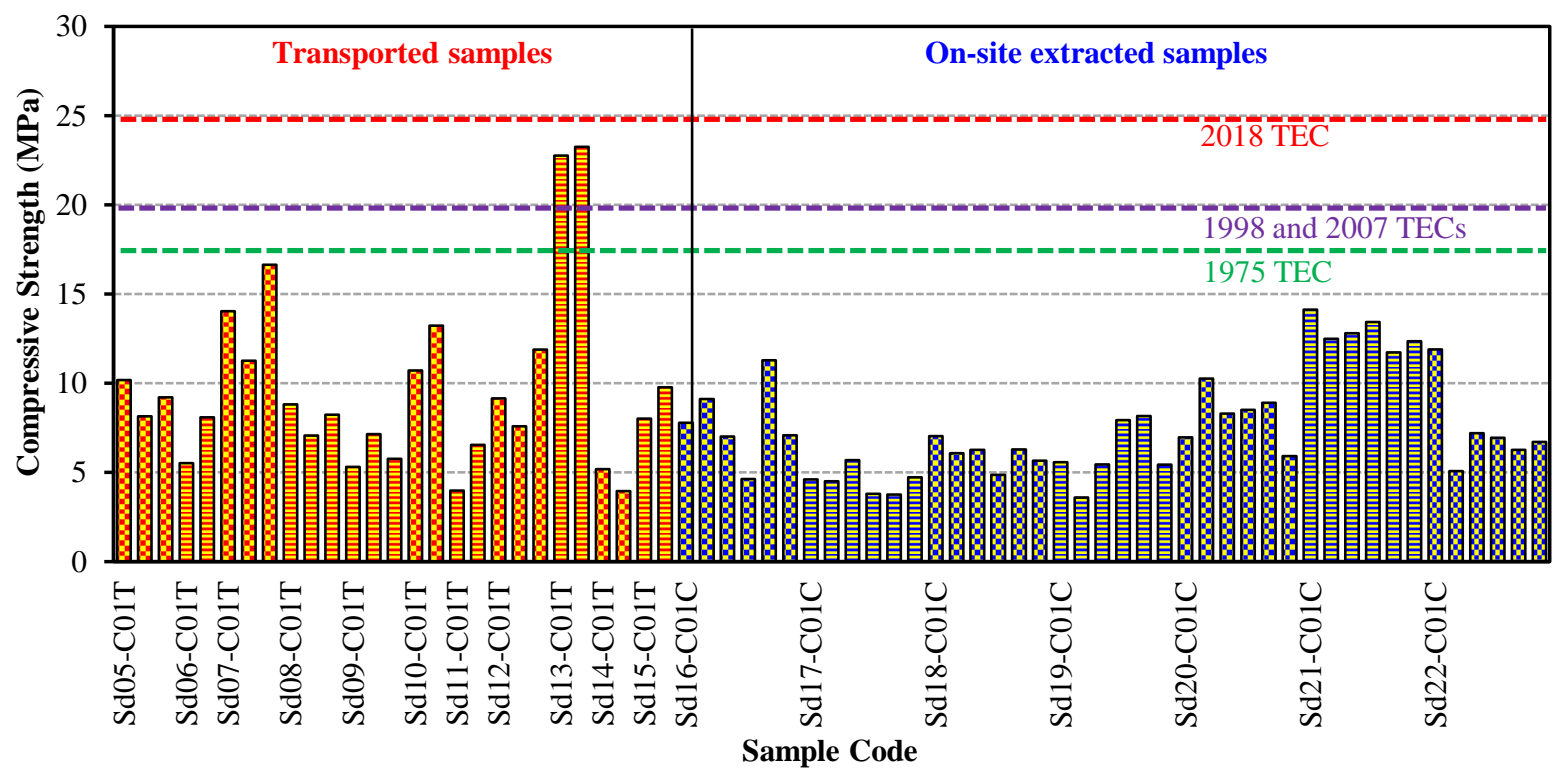

Figure 8: Compressive strengths of the concrete core samples of severely damaged buildings.

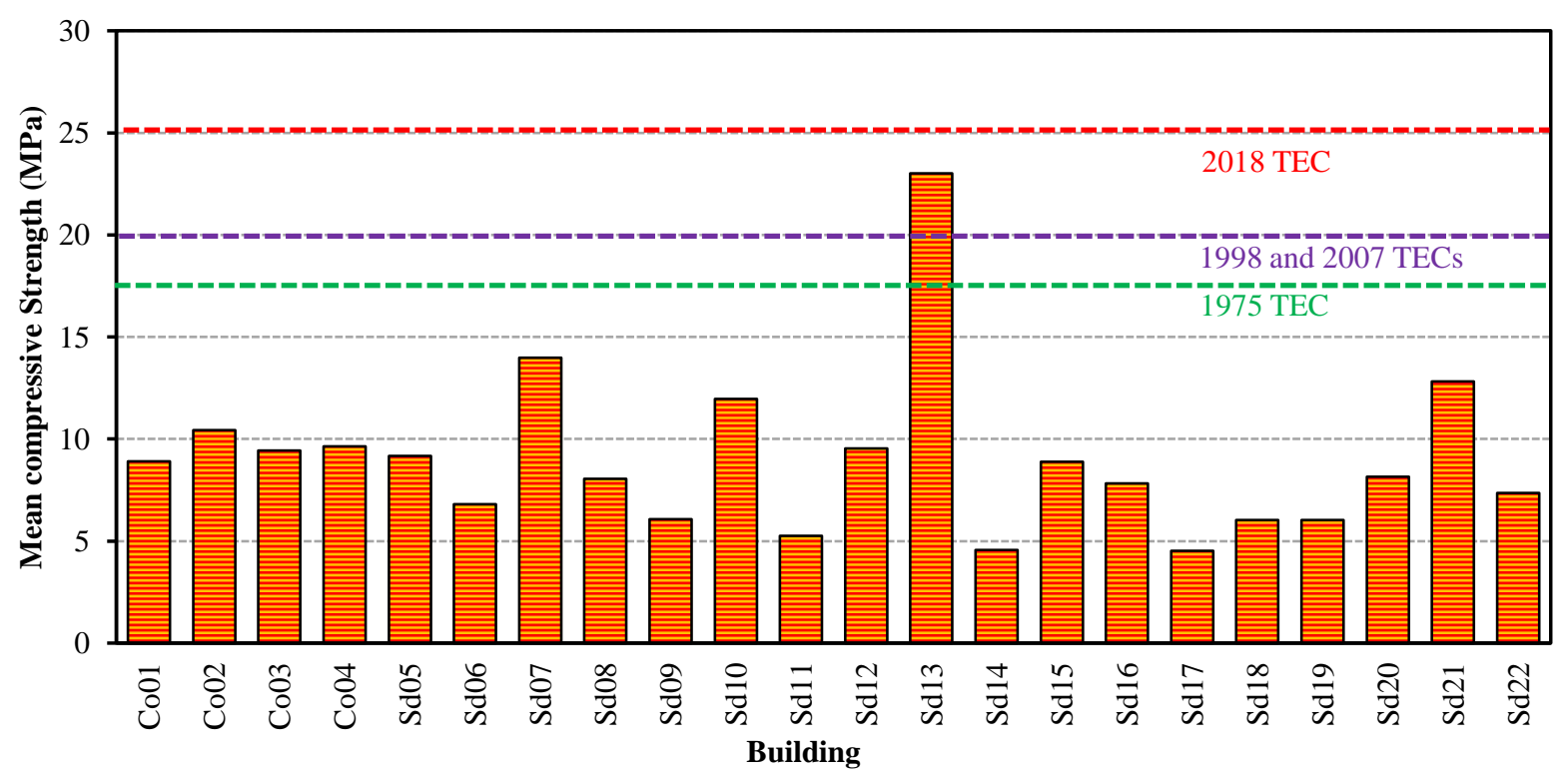

Figure 9: Mean compressive strengths of the concrete core samples of collapsed/severely damaged buildings. 
Table 2: Tensile test results of reinforcements of severely damaged buildings.

\begin{tabular}{|c|c|c|c|c|c|c|c|c|c|c|c|c|}
\hline Sample Code & $\begin{array}{l}\text { Reinf. } \\
\text { Type }\end{array}$ & $\begin{array}{c}\text { Nominal } \\
\text { Diameter } \\
\text { mm }\end{array}$ & $\begin{array}{c}\text { Measured } \\
\text { Diameter } \\
\text { mm }\end{array}$ & $\begin{array}{c}\text { Rupture } \\
\text { Elongation } \\
\% \\
\end{array}$ & $\mathbf{I}$ & $\begin{array}{c}\text { Yield St }{ }^{\mathrm{II}} \\
\mathbf{N} / \mathbf{m m}^{2}\end{array}$ & III & IV & $\begin{array}{c}\text { Tensile St. }^{\mathrm{V}} \\
\mathrm{N} / \mathbf{m m}^{2}\end{array}$ & VI & $\begin{array}{c}\mathrm{V} / \mathrm{II} \\
\%\end{array}$ & VII \\
\hline Sd05-R01 & S220 & 8.0 & 7.8 & 30.30 & $\sqrt{ }$ & 638.3 & $\sqrt{ }$ & - & 721.4 & $\sqrt{ }$ & 1.13 & $\mathrm{X}$ \\
\hline Sd05-R02 & S220 & 10.0 & 10.0 & 28.75 & $\sqrt{ }$ & 388.6 & $\sqrt{ }$ & - & 497.3 & $\sqrt{ }$ & 1.28 & $\sqrt{ }$ \\
\hline Sd05-R03 & S220 & 16.0 & 16.0 & 29.82 & $\sqrt{ }$ & 531.5 & $\sqrt{ }$ & - & 544.5 & $\sqrt{ }$ & 1.02 & $\mathrm{X}$ \\
\hline Sd06-R01 & S220 & 8.0 & 8.1 & 38.84 & $\sqrt{ }$ & 308.9 & $\sqrt{ }$ & - & 438.6 & $\sqrt{ }$ & 1.42 & $\sqrt{ }$ \\
\hline Sd06-R02 & S220 & 8.0 & 8.1 & 23.07 & $\sqrt{ }$ & 481.4 & $\sqrt{ }$ & - & 766.0 & $\sqrt{ }$ & 1.59 & $\sqrt{ }$ \\
\hline Sd06-R03 & S220 & 8.0 & 8.0 & 25.78 & $\sqrt{ }$ & 429.9 & $\sqrt{ }$ & - & 493.8 & $\sqrt{ }$ & 1.15 & $X$ \\
\hline Sd06-R04 & S220 & 14.0 & 14.1 & 32.05 & $\sqrt{ }$ & 406.8 & $\sqrt{ }$ & - & 446.4 & $\sqrt{ }$ & 1.10 & $\mathrm{X}$ \\
\hline Sd06-R05 & S220 & 14.0 & 13.9 & 47.71 & $\sqrt{ }$ & 228.5 & $\sqrt{ }$ & - & 311.9 & $\mathrm{X}$ & 1.37 & $\sqrt{ }$ \\
\hline Sd07-R01 & $\mathbf{S 4 2 0}$ & 8.0 & 8.1 & 24.49 & $\sqrt{ }$ & 410.9 & $\mathrm{X}$ & $\sqrt{ }$ & 639.3 & $\sqrt{ }$ & 1.56 & $\sqrt{ }$ \\
\hline Sd07-R02 & S420 & 8.0 & 7.9 & 32.87 & $\sqrt{ }$ & 313.2 & $\mathrm{X}$ & $\sqrt{ }$ & 442.4 & $\mathrm{X}$ & 1.41 & $\sqrt{ }$ \\
\hline Sd07-R03 & $\mathbf{S 4 2 0}$ & 16.0 & 16.1 & 20.07 & $\sqrt{ }$ & 485.8 & $\sqrt{ }$ & $\sqrt{ }$ & 689.2 & $\sqrt{ }$ & 1.42 & $\sqrt{ }$ \\
\hline Sd07-R04 & $\mathbf{S 4 2 0}$ & 16.0 & 16.0 & 28.19 & $\sqrt{ }$ & 443.3 & $\sqrt{ }$ & $\sqrt{ }$ & 709.9 & $\sqrt{ }$ & 1.60 & $\sqrt{ }$ \\
\hline Sd08-R01 & $\mathbf{S 4 2 0}$ & 8.0 & 8.1 & 28.44 & $\sqrt{ }$ & 514.5 & $\sqrt{ }$ & $\sqrt{ }$ & 545.5 & $\sqrt{ }$ & 1.06 & $\mathrm{X}$ \\
\hline Sd08-R02 & $\mathbf{S 4 2 0}$ & 8.0 & 8.1 & 23.12 & $\sqrt{ }$ & 415.6 & $\mathrm{X}$ & $\sqrt{ }$ & 504.1 & $\sqrt{ }$ & 1.21 & $\sqrt{ }$ \\
\hline Sd08-R03 & S420 & 12.0 & 11.9 & 22.26 & $\sqrt{ }$ & 602.6 & $\sqrt{ }$ & $\mathrm{X}$ & 728.2 & $\sqrt{ }$ & 1.21 & $\sqrt{ }$ \\
\hline Sd08-R04 & S420 & 16.0 & 15.8 & 24.32 & $\sqrt{ }$ & 347.9 & $\mathrm{X}$ & $\sqrt{ }$ & 410.6 & $\mathrm{X}$ & 1.18 & $\sqrt{ }$ \\
\hline Sd08-R05 & S420 & 16.0 & 16.1 & 28.82 & $\sqrt{ }$ & 375.2 & $X$ & $\sqrt{ }$ & 441.2 & $X$ & 1.18 & $\sqrt{ }$ \\
\hline Sd09-R01 & S220 & 10.0 & 9.9 & 19.82 & $\sqrt{ }$ & 309.0 & $\sqrt{ }$ & - & 449.9 & $\sqrt{ }$ & 1.46 & $\sqrt{ }$ \\
\hline Sd09-R02 & S220 & 10.0 & 9.8 & 21.82 & $\sqrt{ }$ & 308.0 & $\sqrt{ }$ & - & 448.2 & $\sqrt{ }$ & 1.46 & $\sqrt{ }$ \\
\hline Sd09-R03 & S220 & 16.0 & 16.1 & 18.53 & $\sqrt{ }$ & 361.6 & $\sqrt{ }$ & - & 570.3 & $\sqrt{ }$ & 1.58 & $\sqrt{ }$ \\
\hline Sd09-R04 & S220 & 16.0 & 15.9 & 19.13 & $\sqrt{ }$ & 309.3 & $\sqrt{ }$ & - & 412.5 & $\sqrt{ }$ & 1.33 & $\sqrt{ }$ \\
\hline Sd10-R01 & S420 & 8.0 & 7.9 & 42.40 & $\sqrt{ }$ & 502.4 & $\sqrt{ }$ & $\sqrt{ }$ & 611.1 & $\sqrt{ }$ & 1.22 & $\sqrt{ }$ \\
\hline Sd10-R02 & S420 & 8.0 & 8.0 & 19.20 & $\sqrt{ }$ & 487.9 & $\sqrt{ }$ & $\sqrt{ }$ & 697.4 & $\sqrt{ }$ & 1.43 & $\sqrt{ }$ \\
\hline Sd10-R03 & S420 & 10.0 & 9.9 & 21.07 & $\sqrt{ }$ & 492.8 & $\sqrt{ }$ & $\sqrt{ }$ & 590.2 & $\sqrt{ }$ & 1.20 & $\sqrt{ }$ \\
\hline Sd10-R04 & S420 & 16.0 & 15.5 & 35.70 & $\sqrt{ }$ & 422.8 & $\sqrt{ }$ & $\sqrt{ }$ & 644.8 & $\sqrt{ }$ & 1.53 & $\sqrt{ }$ \\
\hline Sd11-R01 & S220 & 14.0 & 14.0 & 25.03 & $\sqrt{ }$ & 365.4 & $\sqrt{ }$ & - & 463.5 & $\sqrt{ }$ & 1.27 & $\sqrt{ }$ \\
\hline Sd11-R02 & S220 & 14.0 & 13.9 & 38.10 & $\sqrt{ }$ & 317.7 & $\sqrt{ }$ & - & 418.0 & $\sqrt{ }$ & 1.32 & $\sqrt{ }$ \\
\hline Sd11-R03 & S220 & 14.0 & 13.7 & 33.04 & $\sqrt{ }$ & 383.1 & $\sqrt{ }$ & - & 478.1 & $\sqrt{ }$ & 1.25 & $\sqrt{ }$ \\
\hline Sd12-R01 & S220 & 8.0 & 7.9 & 38.80 & $\sqrt{ }$ & 298.8 & $\sqrt{ }$ & - & 401.6 & $\sqrt{ }$ & 1.34 & $\sqrt{ }$ \\
\hline Sd12-R02 & S220 & 10.0 & 9.8 & 21.94 & $\sqrt{ }$ & 459.8 & $\sqrt{ }$ & - & 558.6 & $\sqrt{ }$ & 1.21 & $\sqrt{ }$ \\
\hline Sd13-R01 & S420 & 10.0 & 10.0 & 30.01 & $\sqrt{ }$ & 468.2 & $\sqrt{ }$ & $\sqrt{ }$ & 632.4 & $\sqrt{ }$ & 1.35 & $\sqrt{ }$ \\
\hline Sd13-R02 & S420 & 16.0 & 16.0 & 19.65 & $\sqrt{ }$ & 429.6 & $\sqrt{ }$ & $\sqrt{ }$ & 680.0 & $\sqrt{ }$ & 1.58 & $\sqrt{ }$ \\
\hline Sd14-R01 & S220 & 8.0 & 8.0 & 25.00 & $\sqrt{ }$ & 269.7 & $\sqrt{ }$ & - & 409.2 & $\sqrt{ }$ & 1.52 & $\sqrt{ }$ \\
\hline Sd14-R02 & S220 & 8.0 & 8.0 & 12.39 & $\mathrm{X}$ & 590.8 & $\sqrt{ }$ & - & 684.2 & $\sqrt{ }$ & 1.16 & $\mathrm{X}$ \\
\hline Sd15-R01 & S220 & 8.0 & 8.1 & 30.12 & $\sqrt{ }$ & 411.9 & $\sqrt{ }$ & - & 459.0 & $\sqrt{ }$ & 1.11 & $\mathrm{X}$ \\
\hline Sd15-R02 & S220 & 8.0 & 8.1 & 25.64 & $\sqrt{ }$ & 410.8 & $\sqrt{ }$ & - & 453.3 & $\sqrt{ }$ & 1.10 & $\mathrm{X}$ \\
\hline Sd15-R03 & S220 & 14.0 & 13.8 & 17.87 & $\mathrm{X}$ & 510.5 & $\sqrt{ }$ & - & 729.9 & $\sqrt{ }$ & 1.43 & $\sqrt{ }$ \\
\hline Sd15-R04 & $\mathrm{S} 220$ & 14.0 & 14.1 & 22.40 & $\sqrt{ }$ & 453.3 & $\sqrt{ }$ & - & 709.5 & $\sqrt{ }$ & 1.57 & $\sqrt{ }$ \\
\hline Sd16-R01 & S220 & 8.0 & 7.8 & 29.53 & $\sqrt{ }$ & 367.5 & $\sqrt{ }$ & - & 422.2 & $\sqrt{ }$ & 1.15 & $\mathrm{X}$ \\
\hline Sd16-R02 & S 220 & 8.0 & 7.9 & 29.90 & $\sqrt{ }$ & 362.8 & $\sqrt{ }$ & - & 417.5 & $\sqrt{ }$ & 1.15 & $\mathrm{X}$ \\
\hline Sd16-R03 & S 220 & 14.0 & 14.0 & 40.90 & $\sqrt{ }$ & 342.4 & $\sqrt{ }$ & - & 416.2 & $\sqrt{ }$ & 1.22 & $\sqrt{ }$ \\
\hline Sd16-R04 & S 220 & 14.0 & 13.7 & 50.67 & $\sqrt{ }$ & 333.2 & $\sqrt{ }$ & - & 453.7 & $\sqrt{ }$ & 1.36 & $\sqrt{ }$ \\
\hline Sd16-R05 & S220 & 14.0 & 13.7 & 28.88 & $\sqrt{ }$ & 424.2 & $\sqrt{ }$ & - & 474.2 & $\sqrt{ }$ & 1.12 & $\mathrm{X}$ \\
\hline Sd17-R01 & S220 & 8.0 & 7.8 & 27.38 & $\sqrt{ }$ & 396.0 & $\sqrt{ }$ & - & 452.9 & $\sqrt{ }$ & 1.14 & $\mathrm{X}$ \\
\hline Sd17-R02 & S220 & 8.0 & 7.9 & 29.08 & $\sqrt{ }$ & 344.5 & $\sqrt{ }$ & - & 430.4 & $\sqrt{ }$ & 1.25 & $\sqrt{ }$ \\
\hline Sd17-R03 & S220 & 8.0 & 8.0 & 20.58 & $\sqrt{ }$ & 451.1 & $\sqrt{ }$ & - & 541.2 & $\sqrt{ }$ & 1.20 & X \\
\hline Sd17-R04 & S220 & 14.0 & 14.0 & 31.52 & $\sqrt{ }$ & 296.9 & $\sqrt{ }$ & - & 420.0 & $\sqrt{ }$ & 1.41 & $\sqrt{ }$ \\
\hline Sd17-R05 & $\mathrm{S} 220$ & 14.0 & 13.7 & 26.98 & $\sqrt{ }$ & 338.6 & $\sqrt{ }$ & - & 462.7 & $\sqrt{ }$ & 1.37 & $\sqrt{ }$ \\
\hline Sd17-R06 & S220 & 14.0 & 14.0 & 27.52 & $\sqrt{ }$ & 342.8 & $\sqrt{ }$ & - & 563.7 & $\sqrt{ }$ & 1.64 & $\sqrt{ }$ \\
\hline Sd18-R01 & $\mathrm{S} 220$ & 14.0 & 13.9 & 22.07 & $\sqrt{ }$ & 458.6 & $\sqrt{ }$ & - & 684.5 & $\sqrt{ }$ & 1.49 & $\sqrt{ }$ \\
\hline Sd18-R02 & S220 & 14.0 & 14.1 & 30.26 & $\sqrt{ }$ & 308.1 & $\sqrt{ }$ & - & 431.0 & $\sqrt{ }$ & 1.40 & $\sqrt{ }$ \\
\hline Sd18-R03 & S 220 & 14.0 & 13.6 & 35.24 & $\sqrt{ }$ & 487.9 & $\sqrt{ }$ & - & 589.2 & $\sqrt{ }$ & 1.21 & $\sqrt{ }$ \\
\hline Sd18-R04 & S220 & 14.0 & 14.0 & 27.32 & $\sqrt{ }$ & 345.3 & $\sqrt{ }$ & - & 454.1 & $\sqrt{ }$ & 1.32 & $\sqrt{ }$ \\
\hline Sd19-R01 & S220 & 8.0 & 8.0 & 22.70 & $\sqrt{ }$ & 286.9 & $\sqrt{ }$ & - & 365.1 & $\sqrt{ }$ & 1.27 & $\sqrt{ }$ \\
\hline Sd19-R02 & S220 & 8.0 & 8.1 & 25.93 & $\sqrt{ }$ & 305.2 & $\sqrt{ }$ & - & 422.9 & $\sqrt{ }$ & 1.39 & $\sqrt{ }$ \\
\hline Sd19-R03 & S220 & 10.0 & 9.9 & 18.57 & $\sqrt{ }$ & 457.3 & $\sqrt{ }$ & - & 606.9 & $\sqrt{ }$ & 1.33 & $\sqrt{ }$ \\
\hline Sd19-R04 & S220 & 16.0 & 16.2 & 31.89 & $\sqrt{ }$ & 260.4 & $\sqrt{ }$ & - & 330.7 & $\mathrm{X}$ & 1.27 & $\sqrt{ }$ \\
\hline Sd20-R01 & S220 & 14.0 & 14.2 & 21.33 & $\sqrt{ }$ & 355.7 & $\sqrt{ }$ & - & 422.9 & $\sqrt{ }$ & 1.19 & $\mathrm{X}$ \\
\hline Sd20-R02 & S220 & 14.0 & 14.1 & 25.67 & $\sqrt{ }$ & 381.1 & $\sqrt{ }$ & - & 484.5 & $\sqrt{ }$ & 1.27 & $\sqrt{ }$ \\
\hline Sd20-R03 & $\mathrm{S} 220$ & 16.0 & 15.9 & 19.38 & $\sqrt{ }$ & 324.8 & $\sqrt{ }$ & - & 502.1 & $\sqrt{ }$ & 1.55 & $\sqrt{ }$ \\
\hline Sd20-R04 & $\mathrm{S} 220$ & 16.0 & 15.8 & 23.35 & $\sqrt{ }$ & 298.0 & $\sqrt{ }$ & - & 412.0 & $\sqrt{ }$ & 1.38 & $\sqrt{ }$ \\
\hline Sd20-R05 & S220 & 16.0 & 16.0 & 34.14 & $\sqrt{ }$ & 264.0 & $\sqrt{ }$ & - & 356.4 & $\sqrt{ }$ & 1.35 & $\sqrt{ }$ \\
\hline Sd21-R01 & $\mathbf{S 4 2 0}$ & 14.0 & 13.6 & 32.35 & $\sqrt{ }$ & 280.9 & $\mathrm{X}$ & $\sqrt{ }$ & 477.0 & $\mathrm{X}$ & 1.70 & $\sqrt{ }$ \\
\hline Sd21-R02 & $\mathbf{S 4 2 0}$ & 14.0 & 14.2 & 28.18 & $\sqrt{ }$ & 334.5 & $\mathrm{X}$ & $\sqrt{ }$ & 528.3 & $\sqrt{ }$ & 1.58 & $\sqrt{ }$ \\
\hline Sd21-R03 & S420 & 16.0 & 15.8 & 22.49 & $\sqrt{ }$ & 547.3 & $\sqrt{ }$ & $\mathrm{X}$ & 705.5 & $\sqrt{ }$ & 1.29 & $\sqrt{ }$ \\
\hline Sd21-R04 & S420 & 16.0 & 15.8 & 50.59 & $\sqrt{ }$ & 363.9 & $\mathrm{X}$ & $\sqrt{ }$ & 537.7 & $\sqrt{ }$ & 1.48 & $\sqrt{ }$ \\
\hline
\end{tabular}


Table 2: Tensile test results of reinforcements of severely damaged buildings (Continued).

\begin{tabular}{|c|c|c|c|c|c|c|c|c|c|c|c|c|}
\hline Sample Code & $\begin{array}{l}\text { Reinf. } \\
\text { Type }\end{array}$ & $\begin{array}{c}\text { Nominal } \\
\text { Diameter } \\
\text { mm }\end{array}$ & $\begin{array}{c}\text { Measured } \\
\text { Diameter } \\
\text { mm }\end{array}$ & $\begin{array}{c}\text { Rupture } \\
\text { Elongation } \\
\%\end{array}$ & I & $\begin{array}{l}\text { Yield St }{ }^{\mathrm{II}} \\
\mathbf{N} / \mathbf{m m}^{2}\end{array}$ & III & IV & $\begin{array}{c}\text { Tensile St. }^{\mathbf{V}} \\
\mathrm{N} / \mathbf{m m}^{2}\end{array}$ & VI & $\begin{array}{c}\text { V/II } \\
\% \\
\end{array}$ & VII \\
\hline Sd21-R05 & $\mathbf{S 4 2 0}$ & 16.0 & 16.3 & 19.13 & $\sqrt{ }$ & 485.4 & $\sqrt{ }$ & $\sqrt{ }$ & 603.3 & $\sqrt{ }$ & 1.24 & $\sqrt{ }$ \\
\hline Sd22-R01 & S220 & 14.0 & 14.3 & 43.33 & $\sqrt{ }$ & 333.2 & $\sqrt{ }$ & - & 376.9 & $\sqrt{ }$ & 1.13 & $\mathrm{X}$ \\
\hline Sd22-R02 & S220 & 14.0 & 14.2 & 43.61 & $\sqrt{ }$ & 268.0 & $\sqrt{ }$ & - & 411.8 & $\sqrt{ }$ & 1.54 & $\sqrt{ }$ \\
\hline Sd22-R03 & S220 & 14.0 & 14.2 & 33.84 & $\sqrt{ }$ & 322.1 & $\sqrt{ }$ & - & 413.4 & $\sqrt{ }$ & 1.28 & $\sqrt{ }$ \\
\hline
\end{tabular}

I: Rupture elongation control is $18 \%$ for $\$ 200$ and $10 \%$ for $\$ 420$.

II: Yield strength

III: Minimum yield strength control is $220 \mathrm{MPa}$ for S220 and $420 \mathrm{MPa}$ for S420.

IV: Actual/characteristic yield strength control is 1.30 (for S420 only)

$V:$ Ultimate tensile strength

VI: Minimum tensile strength control is $340 \mathrm{MPa}$ for S220 and $500 \mathrm{MPa}$ for S420.

VII: Ultimate tensile strength/yield strength control is 1.20 for S220 and 1.15 for S420.

\section{WORKMANSHIP ERRORS AND FAILURE OBSERVATIONS}

In Turkey, a highly seismic zone, although the structural members in damaged buildings are generally designed in accordance with the standards and earthquake codes, implementation against the design and serious workmanship errors are frequently encountered in damaged buildings [35, 37-39, 55-58]. In the aftermath of the Elazığ earthquake, similar implementation and workmanship errors have stood out.

\section{Inappropriate Aggregate and Poor Quality of Concrete}

Concrete quality is of utmost importance in RC buildings. Due to the low-quality materials, many fatalities and damages occurred due to earthquakes in Turkey. The factors adversely affecting the concrete quality are as follows: unqualified concrete mix design, improper aggregate gradation, organic materials, lack of compacting, insufficient curing, high water/cement ratio, and the use of rounded sea sand and aggregate in coastal regions, etc. Similar problems regarding concrete quality were also encountered in the collapsed buildings in Elazı $\breve{g}$ (Figure 10).

\section{Reinforcement Corrosion}

An RC member can only resist loads if concrete and steel reinforcement work as a whole with a proper bond in between. Corrosion is a significant problem affecting the adherence between the two materials. One of the most important causes of reinforcement corrosion is salts in the surrounding concrete. Various salt solutions in seawater cause salt content in sand and aggregates taken from the sea. Due to the widespread use of rounded sea aggregate in concrete, corroded reinforcement was also encountered in most Marmara earthquake buildings [30]. Especially in places with high humidity, reinforcement corrosion increases because of insufficient concrete compaction and cover concrete. Similar corrosion problems were also observed in the damaged buildings in the Elazığ earthquake (Figure 11).
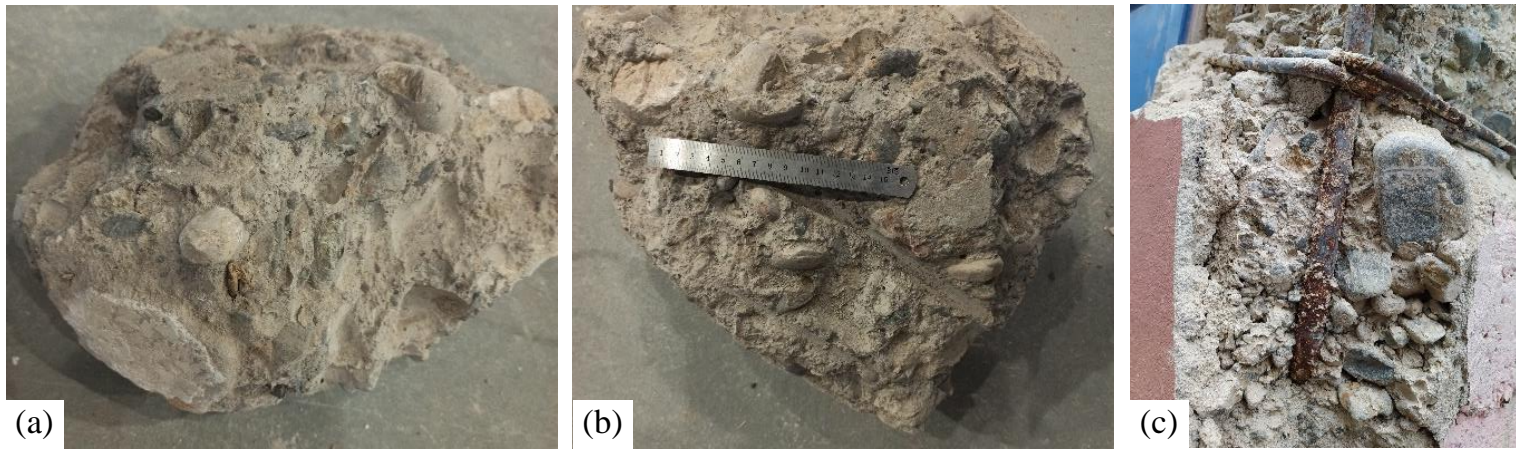

Figure 10: Rounded and poorly gradated aggregates and organic materials in concrete, $(a, b)$ transported concrete pieces, (c) concrete of a column observed on site.
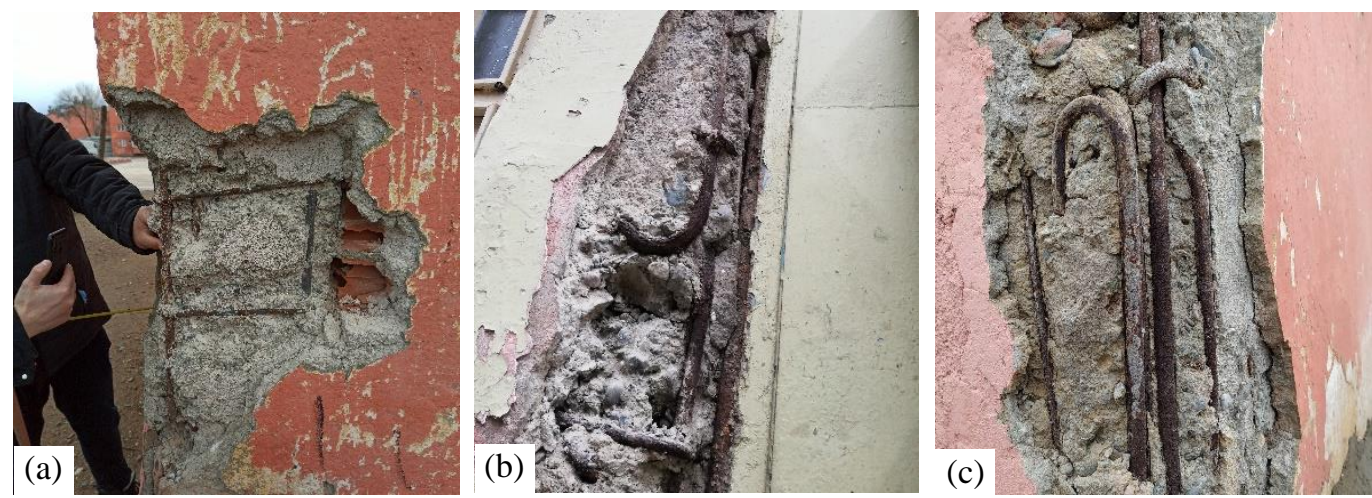

Figure 11: High level of reinforcement corrosion in the buildings in Elazı̆̆, (a) corroded longitudinal and transverse reinforcements, $(b, c)$ visible rust layer on the concrete-rebar contact surface. 


\section{Lap Splice Defects}

Although it was suggested in TECs before 2018 to overlap the longitudinal reinforcement in the middle region of columns, it was still allowed to be provided in the end regions. However, overlapping longitudinal reinforcing bars in the end regions is widespread in Turkey's construction practice. On the other hand, earthquake forces cause high bending moments at the columns' ends. Longitudinal reinforcements are exposed to high tensile and compressive forces. Therefore, it is essential to ensure the tensile continuity of reinforcing bars at the ends of the columns.

The tensile continuity of lap splices is guaranteed by the rules defined in TECs. According to these rules, lap splices must be well confined (details of the confinement rules are explained in the following subsection "Transverse Reinforcement Defects"). In the case of the ribbed longitudinal bars overlapped at the ends of the column, the lap splice length was between 1.25 and 1.5 times the development length $\left(\ell_{b}\right)$ which can be calculated as shown in Equation 1.

$\ell_{b}=\left(0.12 \times \frac{f_{y d}}{f_{c t d}} \times \emptyset\right) \geq 20 \emptyset$

where $f_{y d}$ is the design yield strength of the longitudinal reinforcement; $f_{c t d}$ is the design tensile strength of concrete; and $\emptyset$ is the diameter of the longitudinal bar.
During the earthquakes, the force transmission did not occur properly due to the lack of adequate development length in longitudinal bars and widely spaced transverse reinforcements in lap splices. In the Elazığ earthquake, many severely damaged buildings with insufficient stirrup spacing and development length in lap splices were encountered. (Figure 12).

\section{Transverse Reinforcement Defects}

Transverse reinforcement details have vital importance in seismic performance of reinforced concrete buildings. For example, reinforced concrete members can suffer shear damage due to inappropriate stirrup spacing and insufficient hook length and angle. Before columns reach their bending capacity, stirrup hooks with insufficient length/angle open and cause columns to lose their confinement, which causes shear damage and instability. Especially, insufficient confinement reinforcement in columns and/or stirrups with $90^{\circ}$ hooks that do not effectively work as confinement have been identified as common problems in the buildings damaged in almost all recent earthquakes in Turkey $[28,30,59,60]$. However, according to the 1975 TEC, 1997 TEC, and 2007 TEC, lateral reinforcement spacing shall not be more than $10 \mathrm{~cm}$; stirrups shall always have $135^{\circ}$ hooks at both ends, leaving at least $8 \mathrm{~cm}$ linear length for S420 and a $10 \mathrm{~cm}$ linear length for S220 stirrups. Despite this, insufficient stirrup spacing and hook length, and angle errors were observed in most buildings in Elazı̆ (Figure 13).
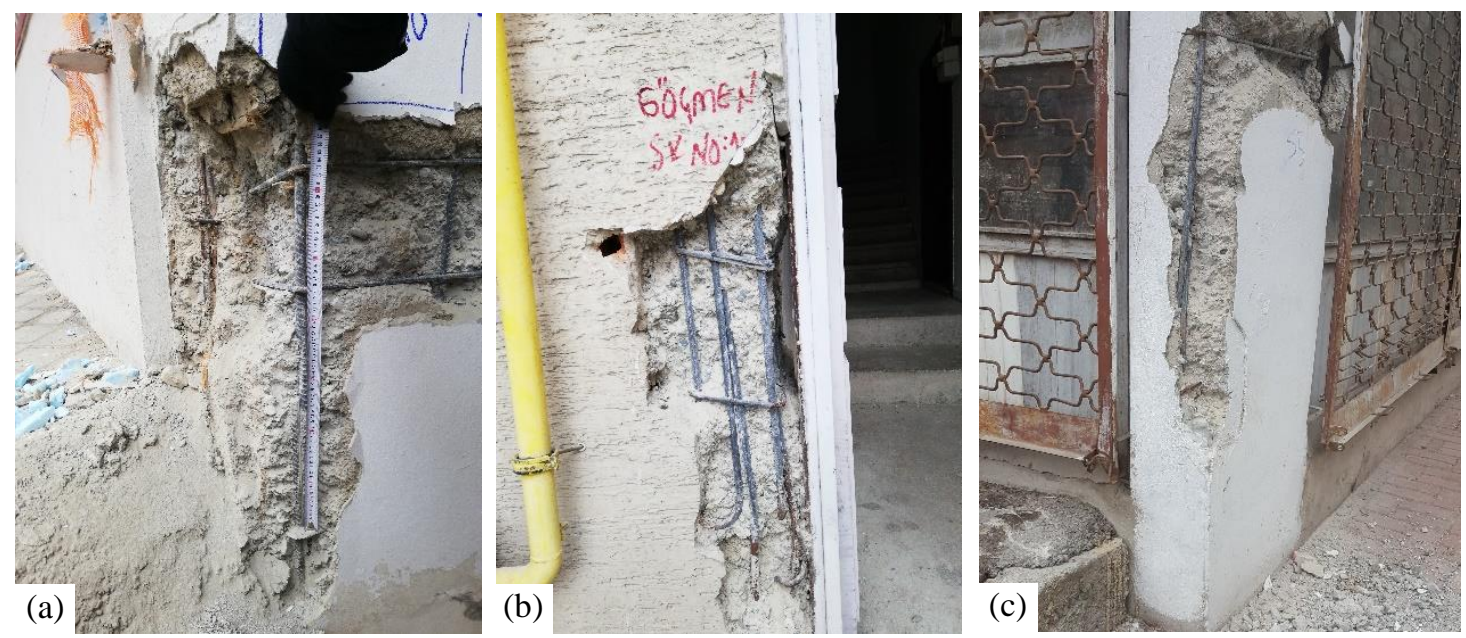

Figure 12: Lap splice defects in damaged buildings in Elazı̆̆ (a) excessive distance between stirrups/stirrup legs, (b) inadequate development length and confinement defects: large spacing and hook angle, (c) $75 \mathrm{~cm}$ stirrup spacing at a lap splice.
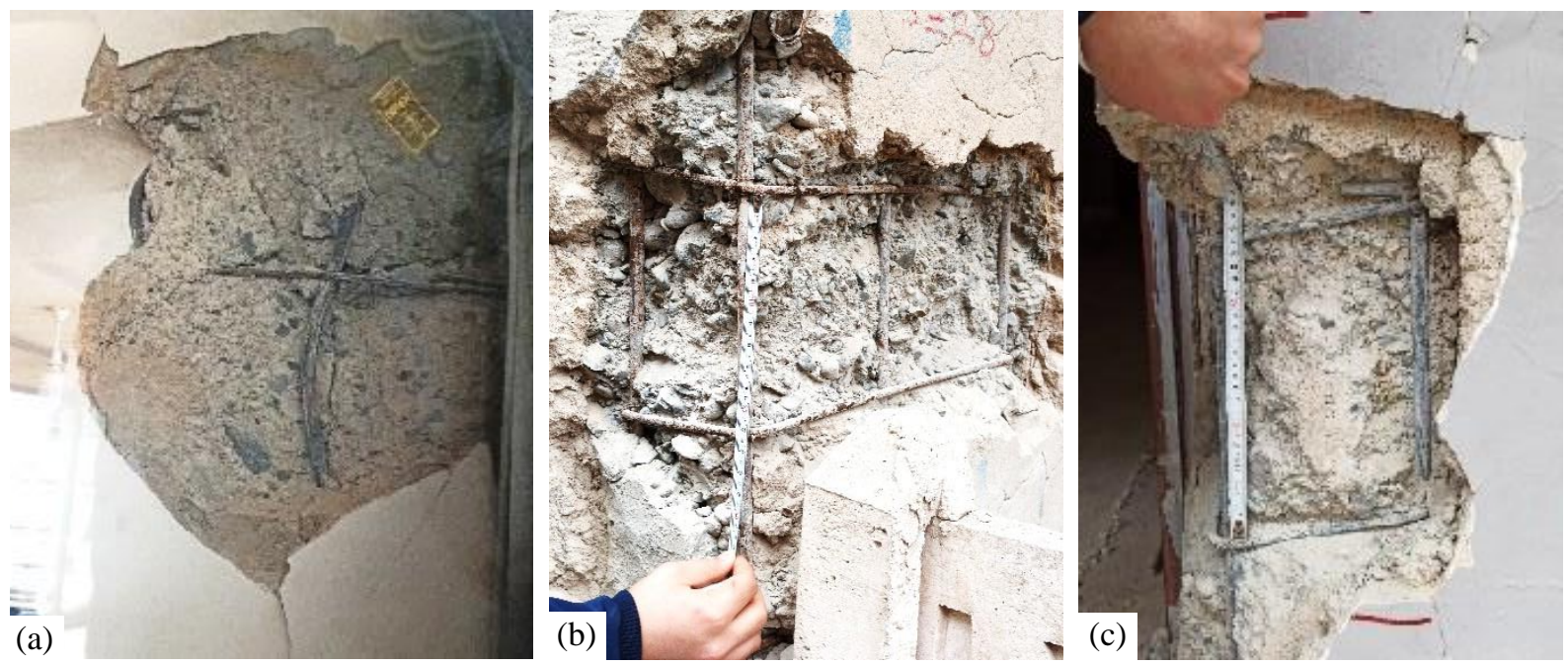

Figure 13: Transverse reinforcement defects in structural members, $(a, b, c)$ Large stirrup spacing, transverse distance between legs and $90^{\circ}$ hook angle in the severely damaged buildings in Elazığ. 


\section{Other Defects and Failure Observations}

Earthquake regulations have great importance for the earthquake resistant design of structures. The requirements in earthquake regulations and standards about reinforcement detail, material quality, structural system configuration, and interaction between the structural - non-structural or structural - structural members exist to eliminate unexpected damages in buildings. On the other hand, it is also essential to correctly implement the design during the construction phase and protect the structural elements/system throughout its service life
However, some design/workmanship defects and improper practices have been observed in field observations. For example, mounting of the building door by welding to column reinforcement (Figure 14a), poor placement of concrete at basement floor column (Figure 14b), not maintaining the column stirrups within the foundation (Figure 14c), lack of sufficient gap between adjacent buildings resulting in hammering/pounding (Figure 14d), installation of electrical cables and water pipes by damaging the structural elements (Figure 14e,f), placing longitudinal reinforcement outside the stirrup (Figure 14g) were encountered during the investigation.
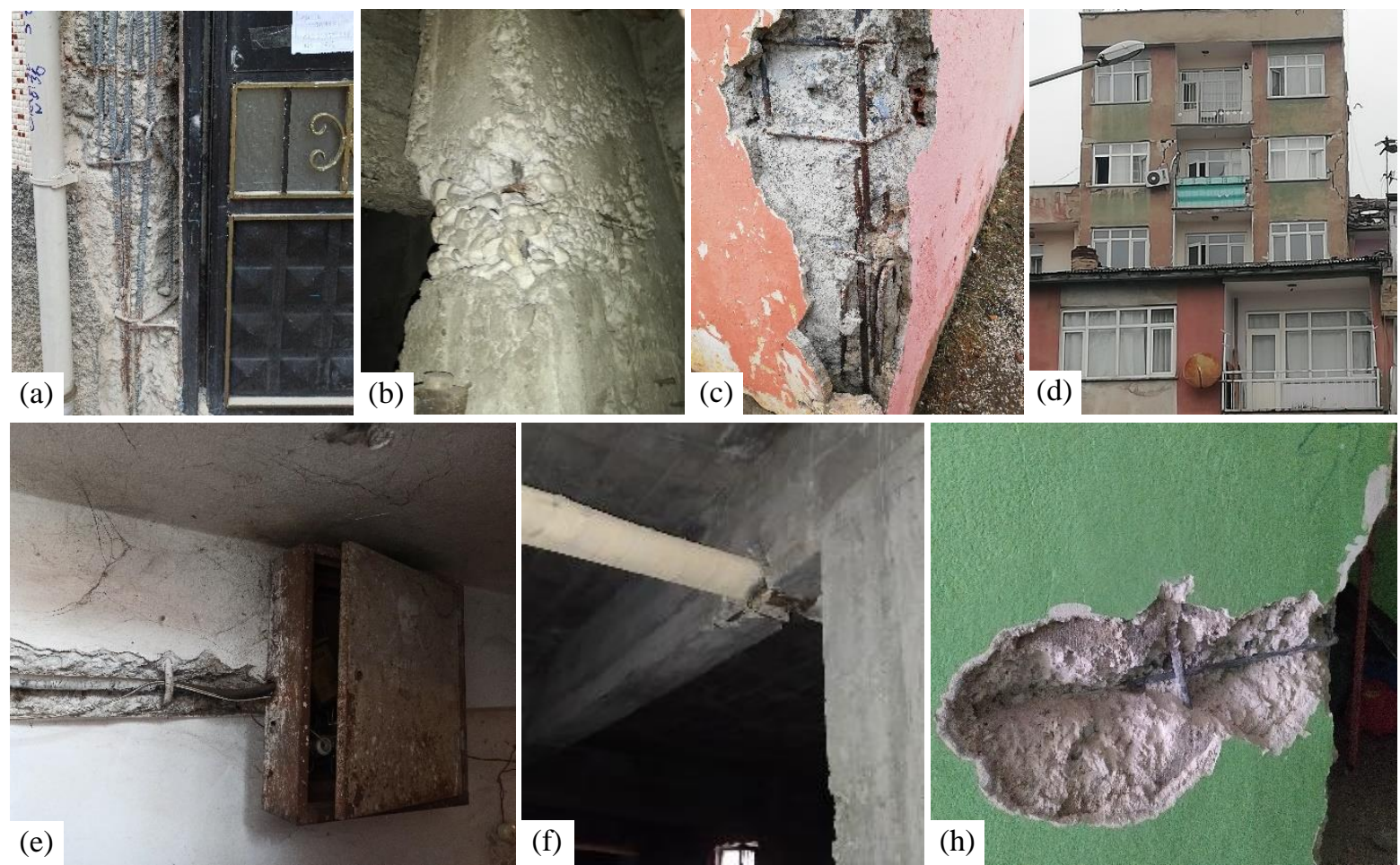

Figure 14: Observed defect examples such as (a) disturbing the column reinforcement due to the door mounting, (b) poor concrete placing, (c) lack of stirrup at the column longitudinal bar extension in the foundation, (d) damage due to the pounding effect, (e) damaging the beam to install electrical cable, $(f)$ damaging the beam to install water pipe, (g) placing the longitudinal rebar out of the stirrup.

\section{RESULTS AND SUGGESTIONS}

The concrete and steel reinforcement samples taken from 4 collapsed and 18 severely damaged buildings in the Sivrice (Elazığ) earthquake were tested. The results' overview is provided for reinforcement in Table 3 and concrete in Figure
15. The maximum, mean, and minimum compressive strength values are shown with the TEC limits (Figure 15). In Table 3, the buildings whose at least one reinforcement sample does not meet at least one criteria regarding yield, tensile, elongation, and ultimate tensile strength/yield strength ratio according to the TS EN 708 standard are marked as "X".

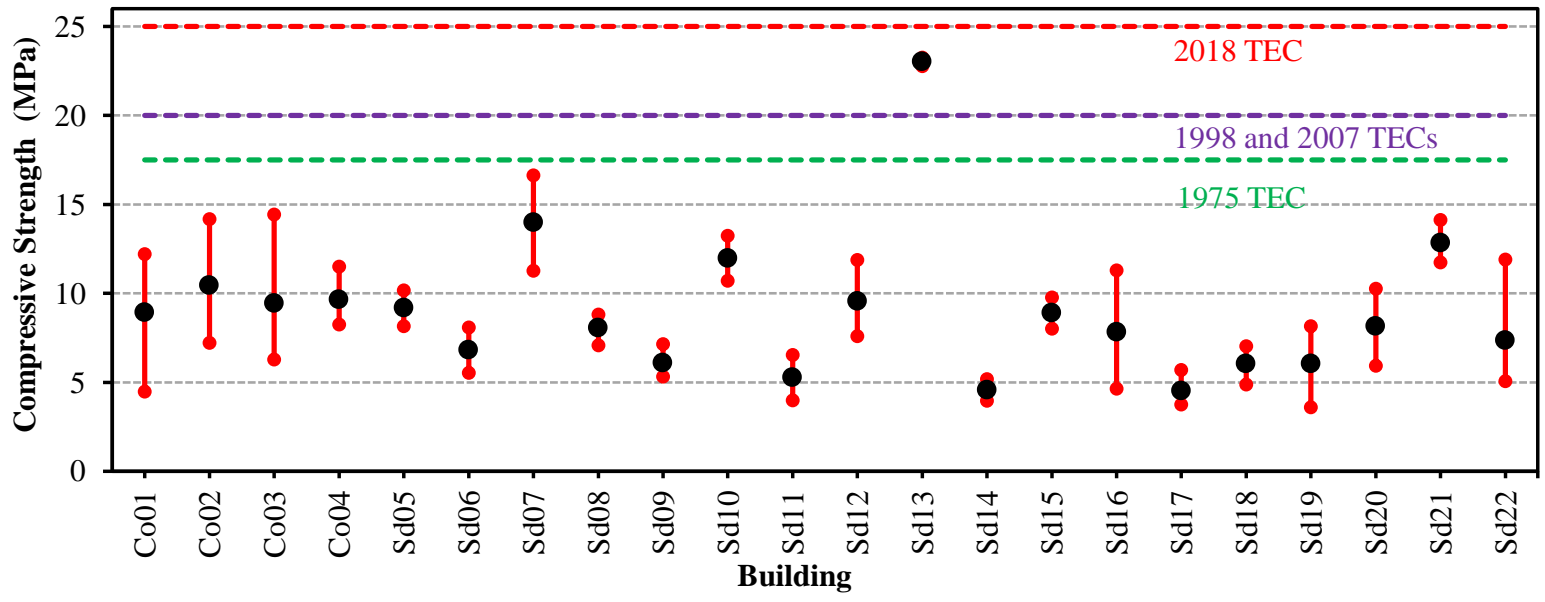

Figure 15: Max, mean and minimum compressive strengths of the concrete samples of collapsed/severely damaged buildings. 
Table 3: Compliance overview reinforcement samples taken from collapsed and severely damaged buildings.

\begin{tabular}{cccc}
\hline Building & $\begin{array}{c}\text { Compliance to } \\
\text { TS EN 708* }\end{array}$ & Building & $\begin{array}{c}\text { Compliance to } \\
\text { TS EN 708* }\end{array}$ \\
\hline C01 & X & D12 & X \\
C02 & X & D13 & $\sqrt{ }$ \\
C03 & X & D14 & X \\
C04 & X & D15 & X \\
D05 & X & D16 & X \\
D06 & X & D17 & X \\
D07 & X & D18 & $\sqrt{ }$ \\
D08 & $X$ & D19 & X \\
D09 & $\sqrt{D 20}$ & X \\
D10 & $\sqrt{ }$ & D21 & X \\
D11 & $X$ & D22 & X \\
\hline
\end{tabular}

*The samples that do not fulfil at least one of the standard conditions are marked as " $X$ ".

Most of the collapsed/severely damaged buildings examined in this study were built in the 1980/the 1990s. One of the most important reasons for the severe damage of buildings can be that the ready-mixed concrete facility was not widespread in those years. On the other hand, the 1975 TEC was in effect during the years when these buildings were built. However, the 1998 TEC contains much more comprehensive rules than the previous one. Besides, the law on the inspection of buildings in Turkey entered into force in 2001 for 19 pilot provinces, not including Elazığ, which was included in the scope of the building inspection law only in 2011. Some of the deficiencies detected in the damaged buildings can also be attributed to the late arrival of building inspection and construction requirements in the Elazığ province.

Following the earthquake with the magnitude of 6.8 occurring in Elazığ, it is necessary to consider the province of Elazı including all of its districts as a high-risk earthquake zone. This shows the necessity of updating the earthquake map. The current values of required strength of the buildings in the earthquake zones like Elazığ should also be questioned.

This study has revealed that most collapsed and severely damaged buildings' material properties do not fulfil the conditions stated in the relevant standards and regulations. Besides, implementation and workmanship errors are common in those buildings. To prevent similar level of damage occurring in future earthquakes, it is imperative to control the materials quality and construct buildings properly according to their design.

\section{ACKNOWLEDGMENTS}

The authors would like to thank Iskenderun Technical University students Seda YEDEK, Abdullah KARAKAS, Ali Mert DORUCU, Osman F. BAYRAK and Mahmut ATALAN for their assistance.

\section{REFERENCES}

1 Akkar S and Gülkan P (2002). "A critical examination of near-field accelerograms from the Sea of Marmara region earthquakes". Bulletin of the Seismological Society of America, 92:428-447. https://doi.org/10.1785/0120000814

2 Disaster and Emergency Management Presidency (2014). "Müdahale, iyileștirme ve sosyoekonomik açıdan 2011 Van depremi". Ministry of Interior, Ankara, Turkey.

3 Disaster and Emergency Management Presidency (2020). "24 Ocak 2020 Sivrice (Elazığ) Depremi Raporu". Ministry of Interior, Ankara, Turkey, 38.

4 Kandilli Observatory and Earthquake Research Institute (2020). "24 Ocak Sivrice-Elazığ Depremi”. Boğaziçi University, İstanbul, Turkey.
5 Türkiye Hazır Beton Birliği. Elâzığ Depremi İnceleme Raporu.

http://www.thbb.org/teknik-bilgiler/raporlar/elazigdepremi/ (Accessed 01 January 2021)

6 United States Geological Survey. M 6.7 - 10km NNE of Doganyol, Turkey.

https://earthquake.usgs.gov/earthquakes/eventpage/us6000 7ewc/executive (Accessed 23 Mar 2020)

7 Mertol HC, Akış T and Tunç G (2020) "24.01.2020 Elazığ Sivrice Deprem Raporu”. At1lim University, İstanbul, Turkey, 108.

8 Disaster and Emergency Management Presidency. Turkish Accelerometric Database and Analysis System. https://tadas.afad.gov.tr/ (Accessed 01 January 2021)

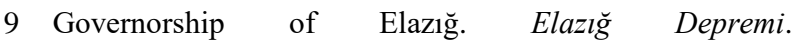
http://www.elazig.gov.tr/elazig-depremi-sonrasi-yapilanyardimlar-merkezicerik (Accessed 23 Feb 2020)

10 Disaster and Emergency Management Presidency (2020). "24 Ocak 2020 Sivrice (Elazı̆̆) Mw 6.8 Depremine Ilişskin Ön Değerlendirme Raporu”. Ministry of Interior, Ankara, Turkey

11 Disaster and Emergency Management Presidency. "Turkey Earthquake Risk Map". https://tdth.afad.gov.tr/ (Accessed 23 Feb 2020)

12 Galloway B and Ingham JM (2015). "The 2014 South Napa Earthquake and its relevance for New Zealand". Bulletin of the New Zealand Society for Earthquake Engineering, 48: 1-30. https://doi.org/10.5459/bnzsee.48.1.1-30

13 Dizhur D, Ingham J, Moon L, Griffith M, Schultz A, Senaldi I, Magenes G, Dickie J, Lissel S, Centeno J, Ventura C, Leite J and Lourenco P (2011). "Performance of masonry buildings and churches in the 22 February 2011 Christchurch earthquake". Bulletin of the New Zealand Society for Earthquake Engineering, 44: 279-296. https://doi.org/10.5459/bnzsee.44.4.279-296

14 Dizhur D, Giaretton M and Ingham J (2017). "Performance of early masonry, cob and concrete buildings in the 14 November 2016 Kaikoura earthquake". Bulletin of the New Zealand Society for Earthquake Engineering, 50: 194-205. https://doi.org/10.5459/bnzsee.50.2.194-205

15 Dizhur D, Simkin G, Giaretton M, Loporcaro G, Palermo A and Ingham J (2017). "Performance of winery facilities during the 14 November 2016 Kaikōura earthquake". Bulletin of the New Zealand Society for Earthquake Engineering, 50: 206-224.

https://doi.org/10.5459/bnzsee.50.2.206-224

16 Baird A and Ferner H (2017). "Damage to non-structural elements in the 2016 Kaikōura earthquake". Bulletin of the New Zealand Society for Earthquake Engineering, 50: 187193. https://doi.org/10.5459/bnzsee.50.2.187-193

17 Roldán R and González A (2016). “Assessment of damage to the ceilings and sprinkler downpipes of an industrial plant from the 2012 7.6MW Sámara earthquake in Costa Rica". Bulletin of the New Zealand Society for Earthquake Engineering, 49: 138-145. https://doi.org/10.5459/bnzsee.49.1.138-145

18 Dhakal RP, MacRae GA and Hogg K (2011). "Performance of ceilings in the February 2011 Christchurch earthquake". Bulletin of the New Zealand Society for Earthquake Engineering, 44: 377-387.

https://doi.org/10.5459/bnzsee.44.4.377-387

19 Dhakal RP (2010). "Damage to non-structural components and contents in 2010 Darfield earthquake". Bulletin of the New Zealand Society for Earthquake Engineering, 43: 404411. https://doi.org/10.5459/bnzsee.43.4.404-411 
20 Crosier J, Hannah M and Mukai D (2010). "Damage to steel storage racks in industrial buildings in the Darfield earthquake". Bulletin of the New Zealand Society for Earthquake Engineering, 43: 425-428. https://doi.org/10.5459/bnzsee.43.4.425-428

21 Buchanan AH and Newcombe MP (2010). "Performance of residential houses in the Darfield (Canterbury) earthquake". Bulletin of the New Zealand Society for Earthquake Engineering, 43: 387-392. https://doi.org/10.5459/bnzsee.43.4.387-392

22 Buchanan A, Carradine D, Beattie G and Morris H (2011). "Performance of houses during the Christchurch earthquake of 22 February 2011". Bulletin of the New Zealand Society for Earthquake Engineering, 44: 342-357. https://doi.org/10.5459/bnzsee.44.4.342-357

23 Kahrizi M and TahamouliRoudsari M (2020). "Seismic performance of school buildings in 2017 Ezgeleh Earthquake, Iran". Bulletin of the New Zealand Society for Earthquake Engineering, 53: 70-82. https://doi.org/10.5459/bnzsee.53.2.70-82

24 Giovinazzi S, Wilson T, Davis C, Bristow D, Gallagher M, Schofield A, Villemure M, Eidinger J and Tang A (2011). "Lifelines performance and management following the 22 February 2011 Christchurch earthquake, New Zealand: Highlights of resilience". Bulletin of the New Zealand Society for Earthquake Engineering, 44: 402-417. https://doi.org/10.5459/bnzsee.44.4.402-417

25 Henry RS, Lee BY, McGuigan D, Finnegan J and Ashby G (2017). "The 2016 Meinong Taiwan earthquake". Bulletin of the New Zealand Society for Earthquake Engineering, 50: 436-468. https://doi.org/10.5459/bnzsee.50.3.436-468

26 Kam WY, Pampanin S and Elwood K (2011). "Seismic performance of reinforced concrete buildings in the 22 February Christchurch (Lyttelton) earthquake". Bulletin of the New Zealand Society for Earthquake Engineering, 44: 239-278. https://doi.org/10.5459/bnzsee.44.4.239-278

27 Binici H, Kaplan H and Görür EB (2005). "Türkiye'de yaşanan son depremlerde malzeme kalitesi ve kötü işçiliğin neden olduğu hasarlar". Deprem Sempozyumu, March 2325, Kocaeli, Turkey, 703-706 pp

28 Mustafa Kemal University (2011). "23 Ekim 2011 Mw 7.2 Van Depremi Sismik ve Yapısal Hasara Ilisskin Saha Gözlemleri ve Tespitler”. Mustafa Kemal University, Hatay, Turkey, 50.

29 Erdem MM, Bikçe M, Geneş MC, Türker HT and Kaçın S (2015). "23 Ekim 2011 Van Depreminde Y1kılan Binalarda Malzeme Özelliklerinin Araştırılması". $8^{\text {th }}$ National Earthquake Engineering Conference, May 11-15, Istanbul, Turkey, 1251-1259 pp.

30 Çağatay IH (2005). "Experimental evaluation of buildings damaged in recent earthquakes in Turkey". Engineering Failure Analysis, 12: 440-452.

https://doi.org/10.1016/j.engfailanal.2004.02.007

31 Disaster and Emergency Management Presidency (2018). "Turkish Earthquake Code 2018". Ministry of Interior, Ankara, Turkey.

32 Disaster and Emergency Management Presidency (1998). "Turkish Earthquake Code 1998". Ministry of Interior, Ankara, Turkey.

33 Disaster and Emergency Management Presidency (2007). "Turkish Earthquake Code 2007". Ministry of Interior, Ankara, Turkey.

34 Public Works and Settlement Directorate (1975). "Turkish Earthquake Code 1975". Ministry of Public Works and Settlement, Ankara, Turkey.
35 Sengel HS and Dogan M (2013). "Failure of buildings during Sultandagi Earthquake". Engineering Failure Analysis, 35: 1-15. https://doi.org/10.1016/j.engfailanal.2012.09.011

36 Demirel IO, Canbay E, Binici B, Yakut A and Eryurtlu Z (2015). "Gazbeton dolgulu betonarme çerçevelerin deprem performansi üzerine deneysel çalişma". 3 Türkiye Deprem Mühendisliği ve Sismoloji Konferansi (3TDMSK), October 14-16, İzmir, Turkey.

37 Sayin E, Yön B, Calayir Y and Karaton M (2013). "Failures of masonry and adobe buildings during the June 23, 2011 Maden-(Elaziğ) earthquake in Turkey”. Engineering Failure Analysis, 34: 779-791.

https://doi.org/10.1016/j.engfailanal.2012.10.016

38 Bekdaş G, Sayin B, Sola ÖÇ and Güner A (2016). "Assessment of the material quality of damaged structures after earthquake in Van, Turkey". Journal of Materials in Civil Engineering, 28(10): 04016110 https://doi.org/10.1061/(ASCE)MT.1943-5533.0001616

39 Bikçe M and Çelik TB (2016). "Failure analysis of newly constructed RC buildings designed according to 2007 Turkish Seismic Code during the October 23, 2011 Van earthquake". Engineering Failure Analysis, 64: 67-84. https://doi.org/10.1016/i.engfailanal.2016.03.008

40 Karaesmen E (1996). Deprem ve Sonrasl. Türkiye Müteahhitler Birliği, Ankara, Turkey, 172.

41 Sanz B, Planas J and Sancho JM (2013). “An experimental and numerical study of the pattern of cracking of concrete due to steel reinforcement corrosion". Engineering Fracture Mechanics, 114: 26-41. https://doi.org/10.1016/j.engfracmech.2013.10.013

42 Apostolopoulos CA (2008). "The effect of ribs on the mechanical behavior of corroded reinforcing steel bars S500s under low-cycle fatigue". Materials and Structures/Materiaux et Constructions, 41: 991-999. https://doi.org/10.1617/s11527-007-9300-7

43 Bikçe M (2016). "A database for fatalities and damages due to the earthquakes in Turkey (1900-2014)". Natural Hazards, 83: 1359-1418. https://doi.org/10.1007/s11069-016-2397-7

44 Zhao B, Taucer $F$ and Rossetto $T$ (2009). "Field investigation on the performance of building structures during the 12 May 2008 Wenchuan earthquake in China". Engineering Structures, 31: 1707-1723. https://doi.org/10.1016/j.engstruct.2009.02.039

45 Sezen H, Whittaker AS, Elwood KJ and Mosalam KM (2003). "Performance of reinforced concrete buildings during the August 17, 1999 Kocaeli, Turkey earthquake, and seismic design and construction practice in Turkey". Engineering Structures, 25: 103-114. https://doi.org/10.1016/S0141-0296(02)00121-9

46 Artioli E, Battaglia R and Tralli A (2013). "Effects of May 2012 Emilia earthquake on industrial buildings of early '900 on the Po river line". Engineering Structures, 56: $1220-1233$. https://doi.org/10.1016/j.engstruct.2013.06.026

47 Alarcon C, Hube MA, Jünemann R and de la Llera JC (2015). "Characteristics and displacement capacity of reinforced concrete walls in damaged buildings during 2010 Chile earthquake". Bulletin of Earthquake Engineering, 13: 1119-1139. https://doi.org/10.1007/s10518-015-9727-0

48 Lagomarsino S, Cattari S, Ottonelli D and Giovinazzi S (2019). "Earthquake damage assessment of masonry churches: proposal for rapid and detailed forms and derivation of empirical vulnerability curves". Bulletin of Earthquake Engineering, 17: 3327-3364. https://doi.org/10.1007/s10518-018-00542-8 
49 Oymael S and Yeğinobalı A (1994). "Elazığ yöresinde hazır beton uygulamaları". 3. Ulusal Beton Kongresi, October 19, İstanbul, Turkey, 129-140 pp.

50 Turkish Standards Institution (2000). "Requirements for Design and Construction of Reinforced Concrete Structures". TS 500, Ministry of Industry and Technology, Ankara, Turkey.

51 Turkish Standards Institution (2019) "Testing Concrete in Structures - Part 1: Cored Specimens - Taking, Examining and Testing in Compression”. TS EN 12504-1, Ministry of Industry and Technology, Ankara, Turkey.

52 ASTM International (2020) "Standard Test Method for Obtaining and Testing Drilled Cores and Sawed Beams of Concrete". C42/C42M-20, American Society for Testing and Materials, West Conshohocken. https://doi.org/10.1520/C0042_C0042M-20

53 Public Works and Settlement Directorate (1996). "Turkey Earthquake Zones Map". Ministry of Public Works and Settlement, Ankara, Turkey.

54 Turkish Standards Institution (2016). "Steel for the Reinforcement of Concrete - Reinforcing Steel”. TS 708 Ministry of Industry and Technology, Ankara, Turkey.

55 Bikce M (2011). "How to reduce short column effects in buildings with reinforced concrete infill walls on basement floors". Structural Engineering and Mechanics, 38: 249259. https://doi.org/10.12989/sem.2011.38.2.249
56 Kaplan H, Yılmaz S, Binici H, Yazar E and Çetinkaya N (2004). "May 1, 2003 Turkey-Bingöl earthquake: damage in reinforced concrete structures". Engineering Failure Analysis, 11: 279-291.

https://doi.org/doi:10.1016/j.engfailanal.2003.08.005

57 Binici H (2007). "March 12 and June 6, 2005 BingolKarliova earthquakes and the damages caused by the material quality and low workmanship in the recent earthquakes". Engineering Failure Analysis, 14: 233-238. https://doi.org/10.1016/j.engfailanal.2005.10.020

58 Celep Z, Erken A, Taskin B and Ilki A (2011). "Failures of masonry and concrete buildings during the March 8, 2010 Kovancilar and Palu (Elaziĝ) Earthquakes in Turkey". Engineering Failure Analysis, 18: 868-889. https://doi.org/10.1016/j.engfailanal.2010.11.001

59 Kandilli Observatory and Earthquake Research Institute (2003). "1 Mayls 2003 Bingöl Depremi Ön Raporu”. Boğaziçi University, İstanbul, Turkey.

60 Earthquake Engineering Research Center (2011). "23 Ekim 2011 Mw 7.2 Van Depremi Sismik ve Yapısal Hasara İlişkin Saha Gözlemleri”. Middle East Technical University, Ankara, Turkey. 